\title{
Person-Centered Psychotherapy \& Adlerian Psychotherapy: Impact on Occupational Stress in Greek Women
}

\author{
Michael Galanakis, Anna Anastasopoulou \\ International College of Psychological Studies (ICPS), Athens, Greece \\ Email: galanakismichael@hotmail.com
}

How to cite this paper: Galanakis, M., \& Anastasopoulou, A. (2020). Person-Centered Psychotherapy \& Adlerian Psychotherapy: Impact on Occupational Stress in Greek Women. Psychology, 11, 499-540.

https://doi.org/10.4236/psych.2020.113034

Received: February 13, 2020

Accepted: March 28, 2020

Published: March 31, 2020

Copyright (c) 2020 by author(s) and Scientific Research Publishing Inc. This work is licensed under the Creative Commons Attribution International License (CC BY 4.0).

http://creativecommons.org/licenses/by/4.0/

\begin{abstract}
The purpose of the present study is to investigate in the time of the great economic recession, the occupational stress experienced by self/employed women in Greece and whether two different kinds of psychotherapy (Person-Centered and Adlerian) affect stress levels. Using the ASSET questionnaire, the study is based on a sample of 178 women, grouped in 3 categories: those that have had at least 6 months of Person-Centered Psychotherapy (59), those that have had at least 6 months of Adlerian Psychotherapy (59) and those that have never had any kind of psychotherapy (60). The effect of the 3 psychotherapeutic conditions on 12 stress factors is examined through various inferential statistical methods. The results suggest that the Person-Centered psychotherapy may affect the "sense of control" and the perceived "work-life balance" in the working environment of the individual, while the Adlerian approach may be related to the broader "psychological well-being" of the person. The findings provide important insights to our knowledge on working stress in women and can be used as a stepping stone in further elaborating the female stress in crisis-stricken countries, or extended to different cases.
\end{abstract}

\section{Keywords}

Work Stress, Occupational Stress, Economic Crisis, Person-Centered Therapy, Rogerian Psychotherapy, Adlerian Psychotherapy, Individual Psychotherapy, ASSET Questionnaire, Perceived Control at Work,

Perceived Work-Life Balance, Psychological Well-Being

\section{Introduction}

Work stress gained attention in the second half of the 20th century, as a crucial societal issue. Considered a "life-structuring concept" in the 60 s, the emphasis 
on work stress "shifted towards" its "apolitical occupational health aspects" with an emphasis on the "micro-level characteristics as factors affecting work stress" and the "study of specific occupational stress models and/or risk factors" (Väänänen et al., 2012).

Before proceeding to the theoretical backbone of this research, a quick view on the Greek economy during the 2008-2018 decade is worth taking. Up until 2007, the economic statistics were upward trending: Real Gross Domestic Product (GDP) both yearly and quarterly levels were positive and in an up-trending territory; the economic sentiment was above 100 and facing north, and unemployment was in the single digit area. In 2007 the above figures stagnated, only to assume a turn for the worse in 2008: real GDP was at -0.8 at the close of 2008, roughing at $-9.2 \%$ in 2011 and remaining negative until 2014, only to resume a negative position after the government change in 2015, up until 2017. Similarly the economic sentiment indicator, dropped below 100 on the 30/9/2008, with two lows in 2009 (75.3, with the subsequent request for help by the International Monetary Fund) and 2012 ( 77.3 where a haircut of 53+\% on the Greek Government Debt holders was imposed) only to barely resurface above 100 in 2014, and dropping again below once the government changed, till the end of 2017. Finally, unemployment entered the double digit area in 2009, peaking close to $28 \%$ in 2013 and remaining above $20 \%$ until 2018. It thus becomes evident that the 2008-2018 decade had a severe toll on both the economic activity, financial stability and prosperity of the country as well as the employment conditions and disposable income of its residents, thus potentially increasing the stress and work stress levels experienced by the Greeks, as can be inferred by such articles as Kalogeropoulou \& Papathanasopoulou (2013), Ntelézos et al. (2014), Papaïoánnou et al. (2018), Sarídi et al. (2016).

\section{Literature Review}

Although stress has been dubbed as "hardship" or "adversity", since the $14^{\text {th }}$ century (Lumsden, 1981), it was after WWII that it became evident that many ordinary life conditions-for example marriage, growing up, facing school exams, and being ill- "could produce effects comparable to those of combat" (Lazarus, 1993). After WWII the "dominant model was basically that of input (load or demand on systems) and output (strain, deformation, breakdown)" ... approached by behaviorism and positivism (Lazarus, 1993). The main interest came from the military to select "stress resistant" soldiers, and "train them to manage stress" and the focus was on explaining and predicting it (Lazarus, 1993). The "stressful conditions did not produce dependable effects" and soon, it was concluded that to "understand what was happening" the "individual differences in motivational and cognitive variables, which intervened between the stressor and the reaction" needed to be taken into account (Lazarus et al., 1952). Cooper and Marshal (1978) define stress as "that quality of experience, produced through a person-environment transaction that, through either over-arousal or under-arousal, results in psy- 
chological or physiological distress" (Aldwyn, 2009: p. 24). Pearlin and Schooler (1978) separate between the "stressor" (referring to external events) and "strain" (internal stressful states), Seyle (1976) used "stressor" to denote the agent, and "stress" to denote the reaction", while Mason (1975) suggested that stress may relate to 3 different situations:

1) Internal state of the organism (or strain: physiological, emotional and cellular reactions);

2) External event (or stressor: duration, rapidity or linkage); and

3) An experience arising from the transaction between the person and the environment, a mismatch between the resources an individual possesses and the perceived challenge or need (phenomenological focus on how stress is perceived/appraised, the perceived characteristics and the severity of the problem).

"Sociologists speak of stress as the disturbing agent (e.g. social disequilibrium; Smelser, 1963) and of strain as the collective reaction (e.g. a panic or riot)" (Lazarus, 1993: p. 4). Cohen et al. (1997) define stress as a "process in which environmental demands tax or exceed the adaptive capacity of an organism, resulting in psychological and biological changes that may place a persons at risk for disease" (p. 3).

Lazarus (1993) concludes that irrelevant of the words used to describe the "stress process" one must always consider 4 different processes to be able to assess the entire process:

1) A "causal external or internal agent, which Hooke (Hinkle, 1973) called a load and others call stress or a stressor". He emphasized the person-environment relationship and relational meaning;

2) An "evaluation (by a mind or a physiological system) that distinguishes what is threatening or noxious from what is benign";

3) A "coping processes used by the mind (or body) to deal with stressful demands"; and

4) A "complex pattern of effects on mind and body, often referred to as the stress reaction".

In doing so, Lazarus tried to define a "load" or "stressor" psychologically, speaking of "several kinds of states relevant to psychological stress and emotion (namely, harm, threat, challenge, and benefit)", thus abandoning the idea that stress is merely a "form of activation" which ignored many qualitative (physiological and psychological) differences (Lazarus, 1993: p. 4).

It must be noted though that not all forms of (physically felt) stress are unwelcomed. For example, Seyle (1974) makes the distinction between eustress (protective-anabolic) which is the good kind of stress, associated with positive feelings and healthy bodily states and distress (destructive-catabolic) the bad kind, associated with negative feelings and disturbed bodily states. Lazarus (1966) focuses on the temporal qualities of the stressor in defining stress: he distinguishes between harm, threat, and challenge (Lazarus 1966, 1981; Lazarus \& Launier 1978; Lazarus \& Folkman, 1984). Harm refers to the "irrevocable loss" that has already 
occurred. Threat is the "anticipation of harm" that has not yet taken place but may be imminent, and challenge resembles the threat, only the person feels confident he/she can overcome the "threat" by effective use of his/her coping resources. Lazarus introduces "different antecedent conditions" in the environment and within the person experiencing stress, that result in different consequences, exhibiting the multidimensional nature of stress (Lazarus, 1993). He explains that "appraisal and coping processes shape the stress reaction", and that these processes, in turn are "influenced by variables in the environment and within the person" (p. 7), making a point that stress is "process and change" rather than "structure or stasis" (Lazarus, 1993: p. 8). Thus one can determine stress as the felt tension that one experiences combined with a prolonged felt sense of inadequacy, irrelevant of the source of stress. We can infer that stress occurs when bodily tension is felt mentally and/or physically, by a stressor for a variety of reasons, and if the stressor or its perception by the individual is not managed, then we can have a case of stress overload potentially leading to strain from the ongoing stress. Such a strain can keep an individual from living a normal life (APA, 2013) and can lead to multiple illnesses and diseases. One's job or occupation can be the cause of multiple stressors or strain (Waltz, 2016). Finally, in attempting to quantify and qualify the experienced stress level, the causality of the felt stress is of outmost importance.

According to a report by the American Psychological Association (APA) the top four sources of stress in 2015 were money, work (if employed), family responsibilities, and health concerns (APA, 2015). Work related stress is one of the most important factors of the working life of an individual (Cavanaugh et al., 2000; Chen, W. et al., 2009) and the World Health Organization (WHO, 2015) mentions that occupational stress often stems from unexpected responsibilities and pressures that do not align with a person's knowledge, skills, or expectations, inhibiting one's ability to cope.

The occupational stress theory has developed since the $60 \mathrm{~s}$, in tandem with the historical and political evolution in the Western societies: the general societal and economic changes influenced the way occupational health issues were considered and work stress was perceived as a major hazard threatening employees' health and lowering their productivity (Väänänen et al., 2012). Warfare and industrial production were the main initiators of research on stress and work stress, in attempting to locate the psychological knowledge of the "fittest" candidate for a specific (war) task, and identifying how people cope with difficult/stressful conditions (Danziger, 1997; Miller \& Rose, 2008; Rose, 1990, 1996; van Drunen, van Strien, \& Haas, 2004). The rich findings led to the human resources management movement, shifting the focus from general stress to work stress. With the increasing use of automation and industrialization, there was a shift from production results to the individual person, creating a fertile ground for the humanistic movement; Abraham Maslow (1943) and Carl Rogers (1951) succeeded Taylor and the behavioristic movement, introducing such higher needs as the 
esteem and self-actualization which were expected to "increase intrinsic motivation, decrease alienation, and improve well-being” (Väänänen et al., 2012: p. 786), bringing the focus on the well-being of the individual and the working mind in addition to the physical health creating a trend of late modern trends of deindustrialization, democratization, and individualization.

In his 2001 book, Cooper records the different work stress models making a point that in its nature, stress is transactional but most models evaluate and estimate it in an interactional framework (not transactional) since the latter way is easier to measure and analyze, even though attempts have been made to at least recognize within this context the dynamic-adaptational nature of stress. The models he refers to are the following:

A) Stress Cycle Model (McGarth, 1987): proposes a sequence of events where the demands of an encounter and its outcome(s) are linked through 3 processes: appraisal (how the encounter is interpreted), decision making (selection of a response), and performance (how well the encounter is managed). There is also the "outcomes process" which he describes as the feedback mechanism through which the encounter is re-appraised. In this model, the imbalance or misfit occurs when the consequences of not meeting the demands are perceived as being significant (McGarth, 1987).

B) The P-E fit Model of Stress (French, Caplan \& Van Harrison, 1982-on which the Mashlach burnout model is based): the lack of fit between the characteristics of the person (abilities, values) and the environment (demands, supplies) can lead to unmet individual needs or unmet job demands, which in turn result in strain. Subjective P-E misfit (how the individuals perceive the encounter) increase the likelihood that strain will occur. There is little empirical evidence due to problems in clarifying the exact nature of the misfit and appropriately measuring the constructs involved.

C) Job demands-control model (Karasek, 1979) focuses on the interaction between "job demands" and "job control" (or "job decision latitude", defined in terms of decision authority and skill level) as key to explaining strain-related outcomes. High job demands combined with low decision latitude (or perceived inability to influence tasks and procedures at work) result in increased strain. It related perceived control with stress, debates over how control should be operationalized and questions how the interaction should best be measured. Still the findings replication of this model have produced mixed results (Cooper et al., 2001).

D) General Systems model of Stress approach (Cox \& McKay, 1981) support that the imbalance between the individual's perceptions of environmental demands and his/her ability to cope with those demands, causes a psychological state of strain. The imbalance occurs in a 5-stage sequence: 1) Source of demand, 2) Perception of that demand in relation to coping resources, 3) The recognition of changes in well-being, 4) The evaluation of coping activities, 5) The feedback/reappraisal of the event. They introduce the concept of stress being an "on-going process which 
involves individuals interacting with their environment, making appraisals of that interaction and attempting to cope with it, and sometimes failing to cope the problem that arise" (Cox \& McKay, 1981: p.18).

E) Cybernetic Model for studying work stress (Cummings \& Cooper, 1979) focuses on the stress cycle, "the sequential events that represent the continuous interaction between person and environment (Cummings \& Cooper, 1979: p. 415). The basic premises that behaviour is "directed towards reducing deviations from a specific goal state" (Buckley, 1967: p. 53) and that it involves: a) the detection of strain through the presence of a perceived mismatch between the person's actual and preferred states, b) the selection of an adjustment process, c) the implementation of the adjustment process (-that is coping behaviours), d) the effect of those coping behaviours on the stressful encounter (Cooper et al., 2001). It draws attention to the temporal nature of stressful encounters and hence the need to consider the impact of time on P-E transactions (Cooper et al., 2001).

There are several points of convergence in these models (Kahn \& Byosiere, 1992) in particular a notion that stress includes:

a) The presence of a demand;

b) A set of evaluative processes through which that demand is perceived as significant and taxing in terms of its impact on individual resources or requiring from the individual something other than normal functioning;

c) The generation of a response that typically affects the well-being of the individual.

The interactional work stress models emphasize the perceived presence of certain conditions that may be associated with a number of stress responses, and also predict that various organizational characteristics, situational factors and individual differences moderate this stimulus-response relationship (Tetrick \& LaRocco, 1987). Generally they resulted in 3 types of research applications (Dewe, 1991):

o Identifying, describing and categorizing different stimuli;

o Demonstrating a relationship between the different categories of stimuli and responses;

o Exploring the nature of that relationship by investigating the moderating effects of different organizational, job-specific, and individual-difference variables.

Although the models are not in dispute, there are a number of limitations in their ability to explain the dynamic nature of stress process, leading researchers to question their efficacy (Cooper et al., 2001). They fail to clarify the complexity of the relationship between the person and the environment and do not give full cognizance to the role of the social context within which an encounter takes place (Revenson, 1997). According to Lazarus (1991), they portray an essentially static relationship, where:

1) Adaptation is always synonymous with good fit and maladaptation with misfit (overlooking the fact that the process changes over time and between encounters). 
2) They fail to recognize that individuals may cope with one encounter but not with another (assuming some people always function well while others always function badly);

3) Imply that individuals will always respond in the same way to the same (similar) situations (viewing some environments as essentially "good" while others as essentially "bad").

Identifying aspects of the appraisal process provides the context for exploring the transactional nature of the encounter. The focus then becomes directing research towards the changing nature of the person-environment relationship and re-defining what needs to be measured (Lazarus, 1990: p. 4), considering not only defining and measuring the structural components of the appraisal process but also of the adequacy of contemporary measurement practices in capturing the transactional process itself (Cooper et al., 2001). Adopting the transactional perspective means that no one variable can be said to be stressful because as Lazarus has articulated (Lazarus, 1990), stress "has been defined as a continually changing relationship between the environment and the person" (p. 4). Thus the question arises whether stress research has relied too heavily on psychometric assessment of measurement validity, perhaps at the expense of determining whether the measures actually reflect the reality and experience of those being asked to complete them. Following from this is the more complex question of how the stress process should be investigated (Cooper et al., 2001). For example there the variable-based Spicer (1997), and the person-based (Somerfield, 1997) methods attempting a transactional approach to stress evaluation: the (quantitative, measurable) variable-based methods create a set of constructs reflecting certain aspects of how individuals function; they tend to reduce the dynamics of the stress process to "patterns of empirical relationships [between variables] which can be accommodated in multivariate statistical analysis (Spicer, 1997). On the other hand the (qualitative/descriptive) person-based methods, position the individual (rather than the variables) as the central focus of analysis. Of course there is always the option of Methodological Pluralism, which could better overcome the quantitative/qualitative challenge. Overall, (Cooper et al., 2001) suggests that in trying to approach the work stress factors transactionally, one should consider that:

o Demands and responses can be understood within the context of the evaluative processes that give significance and meaning to the encounters;

o It is through these processes that the individual and the environment are linked;

o It is these processes that best express the relational-transactional nature of work stress;

o Strain occurs when there is an imbalance between the demands of the encounter and the resources of the individual to manage those demands;

o Agreement mainly on the conceptual level and not on the definition and measurement level (Cooper et al., 2001).

Limiting ourselves in the available interactional research on work stress, there 
are still some useful findings that are worth mentioning. Based on existing research (Cooper et al., 2001), the job Related Sources of Strain (stressors) can be grouped into 2 categories:

a) Environmental (job-specific sources \& organizational sources);

b) Individual (personal sources).

Under environmental sources of strain, Cartwright and Cooper (1997) have further differentiated 6 primary work-related stressors: $(1-6=$ stressors within the workplace, $6=$ interplay between the job and life off the job).

1) Factors intrinsic to the job itself, (task context factors (Kahn \& Byosiere, 1990) - include vibration \& temperature, workload, work hours, new technology, exposure to risks and hazards, etc. (Cooper et al., 2001);

2) Roles in the organization-incl. role ambiguity, role conflict, role overload, responsibility;

3) Relationships at work, such as those with supervisors, colleagues, and subordinates-incl. abrasive personalities, leadership styles, etc.

4) Career development issues-incl. job insecurity;

5) Organizational factors, incl. the structures and climate of the organizations as well as its culture and political environment;

6) The home-work interface.

Although stressors are not confronted in isolation from each other (but rather occur in combination) and there is still a debate on whether the stressors should be investigated "objectively" or "subjectively", the transactional model of stress emphasizes that perception of a stimulus or event: if a threat is not perceived, there is no strain felt, irrelevant of its presence or not (Cooper et al., 2001). Spector and Jex (1998) makes a case that both subjective and objective factors should be considered, to better understand how the environment affects people's health and wellbeing.

The stress created by the stressors, can be exhibited by 3 different responses: physical, psychological and behavioural (Kahn \& Byosiere, 1992). The new ideals portrayed by newer management approaches, attempted to normalize mentally stressful working conditions, by portraying an employee able to cope with a variety of challenges using specific characteristics present in him/herself and/or his/her micro-milieu (Kugelmann, 1992; Newton et al., 1995: p. 67). Several moderators have been identified, that can facilitating the stressor-strain relationship and building stress resilience:

a) Personality/Disposition:

- Differential exposure perspective/inferential reactivity perspective (Strawski, 2010);

- Negative Affectivity (Watson \& Clarke, 1984);

- Trait anxiety (Spielberg, 1972);

- Hardiness (Kobasa, 1982; Maddi \& Kobasa, 1984; Orr \& Westman, 1990; Snyder et al., 1991);

- Constructive Thinking (Epstein \& Meier, 1989); 
- Type A personality (Friedman \& Rosenman, 1974);

- Self-Esteem \& Self-Efficacy (Bandura, 1977; Bandura, 1982; Mäkikangas \& Kinnunen, 2003);

- Individual coping mechanisms in a work setting (e.g. Burke \& Belcourt, 1974; Cooper \& Dewe, 2004: p. 99);

- A sense of Coherence (Antonovsky, 1987);

- Optimism (Hayes \& Weathington, 2007; Mäkikangas \& Kinnunen, 2003; Scheier \& Carver, 1987; Tuten \& Neidermeyer, 2004);

- Locus of Control (Parkes, 1991; Ru Hsu, 2011);

- Learned Resourcefulness (Rosenbaum, 1990).

b) Situational Moderators: Perceived control over the environment (Lee \& Brand, 2005; Tetrick \& LaRocco, 1987);

c) Effects of Social support on stressor-strain relationships (Bliese \& Britt, 2001; Carlson \& Perrewé, 1999; Ru Hsu, 2011).

- Sources of support;

- Type of support provided;

- Erosion of buffering effects.

New work-stress aspects were analyzed (for example conflicts between work and non-work life (Greenhaus \& Beutell, 1985), gender differences in work stress daily recovery (Frankenhaeuser et al., 1989), and balance or lack thereof in effort-reward (Siegrist, 1996) making work-stress an interdisciplinary subject of interest, combining the use of "multidisciplinary frameworks and new psychosocial measures, and for usable practical indicators and tools" (Väänänen et al., 2012: p. 792). At the end of the $20^{\text {th }}$ century, the shift away from the Fordist industrial job description towards knowledge-intensive and service jobs, ensued the "holistic management" of the employees, with such management strategies as job enrichment, quality of work life, etc. (Alvesson \& Deetz, 2001: p. 93) including the psychological and emotional management of the employees (Fineman, 2003; Goleman, 1996) increasing the attention on their phenomenology and reinforcing the link between "work stress (emotions), occupational well-being (health), and organizational efficiency (productivity)" (Väänänen et al., 2012: p. 792).

In their article, Decker \& Borgen (1993) examined the relationships among five domains in which workers appraise themselves and their work transactions (stress, strain, coping, job satisfaction, and negative affectivity) and showed that higher stress predicted higher strain and lower job satisfaction, even after the effects of the personality disposition of negative affectivity had been controlled and that "with the addition of the six measures of stress to the model, the predictable variance accounted for by stress increased over and above the variance predicted by negative affectivity". Similarly, Fisher \& Gittelson (1983) state that "the workplace has repeatedly been shown to contribute to people's feelings of well-being or conversely to symptoms and dissatisfaction in their jobs". Using the above moderators, the physiological, psychological and behavioural strain that can result from stress at work (Johnson \& Cooper, 2003) has been substantially 
documented on an interactional level (Cooper et al., 2001).

Due to male domination in the workforce, studies of women and comparisons of both genders have been sparse (Parkes, 1990). Both men and women stress indices peak between the ages of 35 and 39 (Lundberg et al., 1994) and according to Lazarus (1993) keeping the type of stressful encounter constant (work-, health-, or family-related stress) women and men show very similar coping patterns, despite public prejudices to the contrary.

And yet, there are studies showing that the difference in stress experienced by men and women can be attributed both to organismic differences, as well as social/cultural differences in their non-paid family roles, especially when children are involved. Jick \& Mitz (1985) suggest that women tend to exhibit higher rates of psychological distress while men are prone to severe physical illness. Specifically women "tend to exhibit the symptomatology of low emotional well-being to a greater extent [...] [and] higher rates of psychological and emotional discomfort" (p. 410) across countries and job levels.

Traditional gender roles still remain, burdening women with most of the family tasks; that may be one factor underlying the higher rate of psychosomatic symptoms, medication and sick leave from work in women compared to men (Statistics Sweden, 1990). Even though women reach a high educational level and are increasingly engaged in the paid work force, they continue to have the core responsibility for household and child care (Frankenhaeuser et al., 1989; Gutek et al., 1991; Hall, 1991; Kahn, 1991; ODriscoll et al., 1992; Peck, 1985; Wortman et al., 1991).

Kandel et al. (1985) make a point that family roles create lower strain and stress levels than occupational and housework roles, but when they do occur they have more severe psychological wellbeing consequences than occupational strains and stresses; still, multiple roles modify the stress-generated depression impact by a particular role, "with buffering effects of work on marital stress and exacerbating effects of parenthood on occupational stress" (p. 64).

Sorensen et al. (1987) state that controlling for working hours, type A-behavior is more prevalent in women than in men, but the perceived total workload of a female manager is higher than that of any other group, experiencing a greater role-conflict between paid work demands and duties related to household and family, "despite the fact that only $1 / 3$ of them had children below the age of 16 living at home compared with $2 / 3$ in the other groups" (p. 343). Specifically, women reported higher levels of work overload, stress and conflict than men, directly related with the number of children at home.

Full time employed, white collar women workers "have a greater total workload and experience more stress and role conflicts than men", and this gender difference "increases systematically with the number of children living at home" (p. 325), especially in families with three or more children; their personal values and high performance standards combined with the expectations of other people and society at large, restrict their choices in this respect (Lundberg et al., 1994). 
It is worth noting that women living without a partner, assume more [paid] responsibilities, reporting less role conflicts (Lundberg et al., 1994: p. 325). In Lambert's paper (1991), relating sex, job conditions, household characteristics, and work responses, she was unable to support the premise that women maintain higher levels of job satisfaction than men because of lower expectations from the workplace; she explained that "the less stressful and more social nature of women's jobs help compensate for their lack of intrinsic rewards" (p. 360). Stress from work overload and role conflicts could be an important factor causing more health problems among women than among men (Blechman \& Brownell, 1998; Chesney \& Ozer, 1995; Orth-Gomer, Wenger, \& Chesney, 1998).

Family work allocation between partners is also of essence, but overall, women have the main responsibility for almost all unpaid duties in the home as well as for child care contributing to additional stress and role conflicts (Lundberg et al., 1994). Kessler et al. (1985) also provide clear evidence that the cost of caring burdens women substantially more than men. In the (rare) cases where men break the gender roles and assume home and child care responsibilities, they face similar problems (work overload and role conflicts) still having more freedom on the possibilities to choose between paid and unpaid work duties (Lundberg et al., 1994). Children at home, burden women with a greater work overload and more stress, while the effect on men is often the opposite; it tends to be associated with fewer career opportunities for women but not for men; women have less recreation time and significantly higher norepinephrine levels after work than women without children, while men with children reported more time for recreation (Bekker et al., 2000).

In terms of perceived control, men reported more autonomy in their paid work whereas women reported more control at (unpaid) home work, but when reaching the upper managerial levels, both men and women reported more control over their total work situation and less conflict between demands (Lundberg et al., 1994). Still by matching men and women in educational and occupational level, women aiming at a professional career generally face more stress, work overload and inter-role conflicts than men, which likely contribute to the underrepresentation of highly educated women in higher occupational positions (Lundberg et al., 1994).

Across countries, statistics show that married, full-time working women have a greater workload than men, due to the unequal division of labour at home. (Carlsen \& Elm Larsen, 1993; Ekvall, Frankenhaeuser, \& Parr, 1994; Frankenhaeuser et al., 1989; Kahn, 1991). Similar gender distinctions were evident in blue- and white-collar workers all over the world verifying that conditions at work and conditions at home interact in ways that create more stress in employed women than in employed men (Aryee, 1993; Barnett \& Brennan, 1997; Beena \& Poduval, 1992; Conger, Lorenz, Elder, \& Simons, 1993; Eckenrode \& Gore, 1990; Greenglass, Pantony, \& Burke, 1988; Hall, 1990; Lewin-Epstein, 1989; Williams et al., 1997). 
And yet, Andreou et al. (2011) using the perceived stress scale (PSS) on the Greek population, found that divorced or widows females exhibited significant higher stress scores compared to singles and especially to married participants, while Haynes and Feinleib (1980) suggest that "regardless of employment status, women reported significantly more symptoms of emotional distress than men" adding that "working women experienced more job mobility than men and more daily stress and marital dissatisfaction than housewives or men" (p. 133). Levenson et al. (2010) confirmed that women tend to experience larger amounts of work change and the relevant stress that accompanies those changes.

Norcross (1990: pp. 218-220) defines psychotherapy as "the informed and intentional application of clinical methods and interpersonal stances derived from established psychological principles for the purpose of assisting people to modify their behaviors, cognitions, emotions, and/or other personal characteristics in directions that the participants deem desirable" (Campbell et al., 2013; Norcross, 1990: pp. 218-220). Jerome Frank (Kubie \& Frank, 1961) explains that psychotherapy is a healing relationship which uses socially authorized methods in a series of contacts that involve primarily words, acts and rituals.

Practiced through the ages by medics, philosophers and spiritual practitioners, by 1996 there were more than 250 different psychotherapy approaches (MacLennan, 1996) while at the start of the $21^{\text {st }}$ century the number had grown to beyond 1000 (Feltham, 1997). They can be described using different axes:

i) Medical (DSM V) vs humanistic (holistic/non-medical) model;

ii) One-to-one therapy vs group therapy;

iii) Short-term vs long-term;

iv) Uncovering(depth) vs supportive psychotherapy.

Irrelevant of the type of psychotherapy, there is a multitude of research and meta-analysis providing convincing evidence of the efficacy of psychotherapy in general (Smith \& Glass, 1977; APA, 2012; etc.) but also specifically with regards to occupational stress ( $\mathrm{Li}$ et al., 2017), helping, for example, deal with the role and economic strains, created by life/work events, which erode the positive concepts of self (like self-esteem and mastery), leading to stress and depression (Pearlin et al., 1981). For the purpose of this study 2 different kinds of psychotherapy were chosen: Adlerian, and Person-Centered. Using the above criteria, they fall under the humanistic, long-term, supportive categories (may be applied both in groups and individually). Both therapies are accommodative to the client's viewpoint, avoiding or accommodating the "psychotherapist-expert" pitfalls (Henkelman \& Paulson, 2006). A brief preview follows, to provide the basics for each approach.

Developed around the 1900s by Alfred Adler, a pioneer in the area of holistic theory on personality, psychotherapy, and psychopathology, it is a teleological psychological approach, which views the person as a "creative, responsible "becoming" individual, moving towards fictional goals within his/her phenomenological field" (Wedding \& Corsini, 2013). Sometimes inferiority feelings may 
discourage the individual, leading to a self-defeating life-style. The emphasis is placed on a person's ability to adapt to such feelings of inadequacy and inferiority relative to others. This is where individual psychotherapy takes it on to encourage the person, in activating his/her social interest and develop a new life-style through belonging, analysis and action methods (Adler, 1966).

In doing that, Adler focused on early childhood memories, in which the family constellation and the child's struggle to find its place of significance, decode the self-defeating life-style patterns-called private logic (Adler, 1963). In understanding a person, one must understand his/her cognitive organization and life-style, so as to understand the convictions (private logic vs common sense, i.e. conclusions from the individual's apperceptions or a biased mode of apperception) that this person developed early in life.

The approach is phenomenological: "We can succeed only if we are genuinely interested in the other. We must be able to see with his eyes and listen with his ears. He must contribute his part to our common understanding. We must work out his attitudes and his difficulties together. Even if we felt we had understood him, we should have no witness that we were right unless he also understood." (Adler, 1931).

According to Adler, behaviour is guided by the goals (forward looking, whether conscious or not) of a person, not a cause (i.e. past/heredity) and the life-style remains constant unless the convictions change. Thus people move forward towards self-selected goals (life tasks) they feel will give them security, a place in the world, preserving their self-esteem. "Life is not a "being" but a "becoming" (Adler, 1963: p. ix). The ultimate goal to be achieved in life has at times been described as "mastery" (Adler, 1926), "superiority" (Adler, 1926), "completion" (Adler, 1931), "self-actualization" (Goldstein, 1939), "self-realization" (Horney, 1951), “competence” (White, 1957) and "perfection” (Adler, 1964); this goal has the purpose of surviving, overcoming life's problems, contributing to humanity and make the world a better place (Adler, 1964).

Adler distinguished 3 main life-tasks that every person needs fulfill: societal (friends), love-related (family) and vocational (work) (Matheny et al., 2000). These are the 3 pillars on which the psychological wellbeing of every individual rests. In the Individual Psychology, people cannot be studied in isolation: in every interpersonal transaction the focus is on the development of feelings of being a part of a larger social whole, incorporated under the heading of Gemeinschaftsgefühl (=social interest) (Adler, 1964) hence people cannot be studied in isolation, but within all the different constellations (social circles primarily related to the 3 main life tasks) the person exists.

The person must also be approached holistically: in how he/she experiences life, along such axes as un/conscious, mind/body, approach/avoidance, ambivalence and conflict, etc. (Wedding \& Corsini, 2013); all these part-functions, are "subordinate functions of the individual's social goals and style of life" (p. 68). Still the individual has the freedom to choose (non-deterministic) whether he/she 
will waste his/her time in useless tasks, feeding his/her need for superiority (neuroticism) or pursue socially useful goals and become task oriented (which is "the iron logic of social living" (Adler, 1959). That is the criterion to identify what the medical profession considers psychopathology (as a phenomenological approach, there is no such categorization in the Individual Psychology, only neuroticisms are described as the state where one becomes significantly non-co-operational, hesitant, or concerned with one's own superiority). Consequently, because all behaviours are governed by some purpose, psychogenic symptoms must have a psychological/social purpose, while organic symptoms, a somatic purpose (Wedding \& Corsini, 2013).

The feelings of inferiority are felt on the onset of birth for each person, whereby each child develops its private logic (Style of Life), in its attempt to take a place of significance. Adler was the first to realize that the birth order of children forges comparable kinds of private logic, which he categorized and labeled (Watkins, 1986). He also gave great emphasis in day/dream interpretation, suggesting that they represent an access to the unconscious part of our private logic. $\mathrm{He}$ also spent time studying and exploring such issues as homosexuality, addictions, spirituality and ecology from a psychological viewpoint. His main focus was on parent education, and opened several schools for parents across Vienna. The Adlerian approach is applied in group therapy, couples enrichment programs, schools, teacher-education programs, parent- and family education programs, leadership and organizational psychology, democratic approach to parenting and family.

Thus applying the Adlerian approach theory to our research, the occupational stress is expected to be a result of the feelings of inability/inferiority of the questioned women. By doing Adlerian psychotherapy, they may have identified the flaw/skew of their private logic, thus perhaps altering their behaviour to become more aligned in fulfilling their job description/requirements/necessities (the $3 \mathrm{~d}$ pillar). Their contribution may have increased their feeling of belonging to the company/job team, perhaps even acclaiming part of the performance of the team, thus creating a positive self-fulfilling prophecy.

Developed in the beginning of the 1940s by Carl Rogers (1942) this kind of psychotherapy seeks to reinforce the self-actualizing tendency (1957), toward growth and fulfillment (Yalom, 1995) through the presence of the following 6 therapeutic conditions:

1) There is Psychological Contact (minimum essential relationship where client and therapist affect each other's experiential field even if only in a subceived way) (Rogers, 1951).

2) The client is incongruent, experiences distress (vulnerable or anxious (Rogers, 1957)), and this internal pressure, acts as a motivator to: a) engage in productive psychotherapy, b) attempt to become observant and c) proceed to change.

3) The Therapist is congruent but not in an expert/advice-giving role and allowing a human equal contact, so that the client operates "within relationships in a reliable and comprehensible way" (Warner, 2005: p. 103). 
4) The therapist exhibits Unconditional Positive Regards (UPR) towards the client's experience, empowering the client to not judge him/herself, increasing self-acceptance and mollifying any rigidities in his/her conditions of worth (Rogers, 1959). Thus it allows for the observation and examination of the difficult processes, reducing defenses and allowing space for change contemplation. As such, it reinforces the openness to the therapeutic process and forges an alliance with the therapist, thereby increasing the probabilities of therapeutic success.

5) The therapist should also exhibit Empathy reinforcing the role of the companion rather than that of the expert, ensuring the therapist is present in the exact phenomenological perception of the client, creating a deep experiential connection, and giving strength to the client to pursue his/her attempt to explain how things are without censoring things out of fear, guilt or shame. With empathic understanding creates "a real and prizing relationship [which] tends to lower the sense of fear that an individual feels in the face of incongruent experiences" (Warner, 2005: p. 103).

6) The client's perception (to at least a minimal degree) of the therapist's UPR, congruence and empathy (Rogers, 1995) is what makes possible a specific kind of encounter and relation which contains no defenses out of fear, shame or guilt and where the client is motivated to focus on, discover, pursue and modify at will, himself, his core values and his way of being (Rogers, 1995). It is the (dialogical) encounter, in which the therapist brings himself fully and interacts in a mutual and transparent way that is "key to the healing process" (Mearns \& Cooper, 2005: p. 9).

Of these 6 conditions, the therapist's Congruence, Empathy and Unconditional Positive regard, are considered the 3 core conditions. Speierer (1998) suggests that incongruence is omnipresent in every individual at some level, but when a tolerable critical level is surpassed, that is where incongruence becomes pathological. Carl Rogers (1957) considers that it is the incongruence between experience and the conditions of worth that determine one's self-image leading to distress; he supports that this incongruence can be dealt with effectively through the presence of the above 6 conditions, especially empathy, congruence and unconditional positive regards (UPR). Lambers links the "inconsistency of conditions of worth, lack of validation of experience, abuse and emotional neglect" to the inability to form a self-concept, resulting in deriving the sense of self "from the definition others give to his experience"-a very unstable, vulnerable self-concept (in Mearns \& Cooper, 2005). Warner in Cooper et al. (2007: p. 154) supports that "PCA does not deny the enormous range of kinds and intensities of human distres ... But it does deposit deep capacities for self-healing inherent within the human organism that apply across human experiences that seem very different on the surface". Again we have a purely phenomenological approach, where we are only concerned with what the client perceives as his reality, and the only link to a "different reality" is the "reality" of the psychotherapist, through his congruence. 
Thus applying the PCA approach theory to our research, the occupational stress is expected to be a result of the inability of the women asked to adapt/the incongruence created between the experiences at work and their values/self-concepts. What PCA is expected to have created, in comparison to the women who have not had any psychotherapy, is a reduction of their defenses, the adoption of a more expansive/extentional way of thinking, reacting and evaluating, which may have resulted in a more accurate symbolization of the experience, eventually moving the locus of evaluation further within each women, becoming more fluid in processing distressing experiences and reducing/resolving the anxiety, tension and psychological maladjustment to the stressful experience(s) at work.

In terms of its efficacy, Carl Rogers consistently measured the effectiveness of his method, and was very focused on the measuring techniques always citing the results. He applied the person-centered therapy approach to groups, severe psychopathology, schools, teachers, businesses and even politics and more. Gibbard and Hanley (2008), covered a 5-year period to show the effectiveness of PCA in routine clinical practice in primary "with common mental health problems, such as anxiety and depression" but "not limited to individuals with mild to moderate symptoms of recent onset, but [extending to] to people with moderate to severe symptoms of longer duration" (p. 215). Stiles et al. (2008) showed in their research that PCA had similar results to CBT and psychodynamic psychotherapy in UK primary-care routine practice. Choimes (1984) through her research shows that PCA increases self-acceptance.

Carl Rogers was a student of Alfred Adler for a couple of years (1927-1928); although their approaches may appear quite different on the surface, they do share a multitude of similarities (Watts, 1996).

First of all they are both phenomenological, in that they are both interested in identifying how the individual client/patient perceives the world and him/herself, and not in once universal commonly perceived truth. They both focus on the here and now, and the past is of interest only as a comparison to how the client/patient perceives his current status-as a measure of change/progress. The extent of irrelevance of the past, can be identified in Roger's words: "Alfred Adler [among others] lectured to us, for example, and shocked the whole staff by thinking that an elaborate case history was not necessary. I remember how misinformed I thought he must be, since we routinely took case histories fifty to seventy pages in length". [...] "It took me some time to realize how much I had learned from him (Roger, 1967: p. 357).

Both approaches are targeted towards self-understanding, self-knowledge and self-evaluation. Thus the client/patient is the driver of the psychotherapeutic session, towards the direction of his/her choice, towards a meaningful (for him/her) destination (self-actualization); the role of the psychotherapist is ether to implement the 6 therapeutic conditions (PCA-Rogers, 1957) and/or proceed with the Socratic Method (Watts, 1998). Indeed Watts makes a strong case of the similarity of the 6 core conditions to Adler's social interest, especially with regards 
to the role of the therapist (Watts, 1998). As a result both approaches are based on cooperation, respect, empathy, encouragement and real care towards the client/patient. This means that in both cases the therapist is considered to be compeer and of equal status to the client/patient, banning any imposition rights, derived from the status of expertise (for example the couch in psychoanalysis) (Adler, 1966), and negating the use of evaluation and diagnosis for the patient (Fiedler, 1950). They both accept the metaphysical perspective, in a holistic way, as well as the unconscious (but only for the purpose of identifying behavioural patterns that are to be brought to the conscious side (edge of awareness) and not for interpretational reasons).

In Car Roger's words, "I had the privilege of meeting, listening to, and observing Dr. Alfred Adler... Accustomed as I was to the rather rigid Freudian approach of the Institute-seventy-five-page case histories, and exhaustive batteries of tests before even thinking of "treating" a child 4 was shocked by Dr. Adler's very direct and deceptively simple manner of immediately relating to the child and the parent. It took me some time to realize how much I had learned from him'. (cited in Ansbacher, 1990: p. 47)

\section{Method}

This research attempts to identify whether Person Centered Psychotherapy (PCA) and/or Adlerian Psychotherapy (AP) have any positive effect on reducing the work stress levels experienced by women working in the area of Athens, in Greece.

\subsection{Research Design and Variables}

This research is based on the transactional Cooper \& Marshall (1978) stress model, considering the continuous cycle of interactions between the person and the environment (encompassing the impact of time) (Cummings \& Cooper, 1979), extending beyond the simple identification of the key aspects of an encounter (Cooper et al., 2001). Phenomenological in nature, it emphasizes the subjective (rather than objective) perception of a stimulus or event by the individual with a focus on the nature of the misfit, and more specifically whether it is perceived as salient and significant, representing a threat to the person's well-being and requiring actions over and above the normal functioning (Cooper et al., 2001).

In this study, the Cooper \& Marshall (1978) stress model, is blended with additional stress input research, focusing both on the identification of the stressors/hazards in the work place, and the individuals most prone to be harmed by them (Faragher, E. B. et al., 2004). Emphasis is given on findings on such issues as poor colleague/superior relationships, isolation, unfair treatment (Industrial Society, 2001; Kahn et al., 1964), job satisfaction (Warr's (1990)) Job Satisfaction Scale) (Lyne et al., 1994), studies on overload and stress symptoms (French, Caplan, \& Van Harrison, 1982; Industrial Society, 2001), control over the organization and performance of a job (Makin et al., 2000), job security (O'Driscoll \& Cooper, 1996), training, equipment, resources, feedback on their work and being valued 
(HSE, 2000; Industrial Society, 2001), the conflict between work, personal, home and social life (Confederation of British Industry, 1998; Industrial Society, 2001), pay and benefits, commitment of the employee to the organization and the perceived opposite, physical and psychological health (Faragher et al., 2004). Considered as a screening tool, "capable of measuring simply and efficiently the extent to which individual employees are currently exposed to a range of common workplace stressors" (Faragher et al., 2004: 192), it is comprised of the 4 following sections (in parentheses the subdivisions of each category:

1) Perceptions of Your Job (Work relationships, your job, overload, control, job security, resources and communication, work-life balance, pay and benefits);

2) Attitudes towards Your Organization (perceived commitment of company to employees and commitment of employee to the company);

3) Your Health (physical health, psychological well-being);

4) Supplementary Information (demographic, biographical and stress related data).

The first two sections are rated on a six point Likert-type scale while the third one on a four point Likert type scale. The fourth section provides qualitative data offering information on the subject's current job, family, lifestyle and interests, acting as a source for potential physical health and psychological well-being symptoms/signs detection. Out of the $4^{\text {th }}$ section, 7 different items were selected, with the criterion of being easily measured/compared, and for the purpose of being checked as a control variable.

Consequently the relevant variables are the following (Figure $1 \&$ Figure 2):

Independent Variables - Psychotherapy Approach
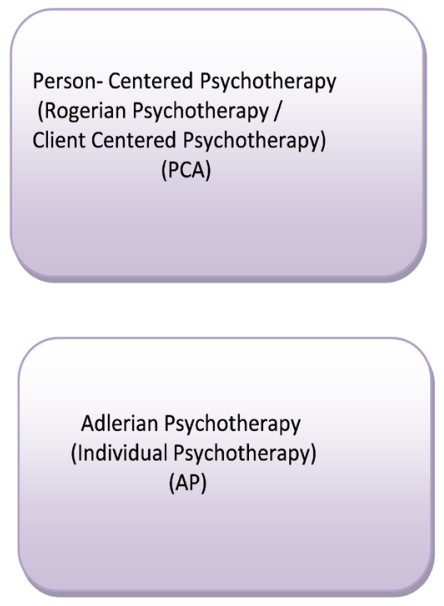

Control Variables
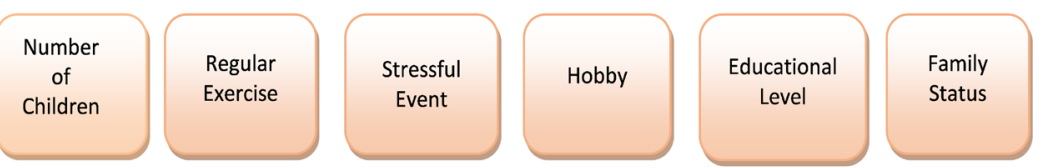

Figure 1. Research design and variables.
Perceived Health
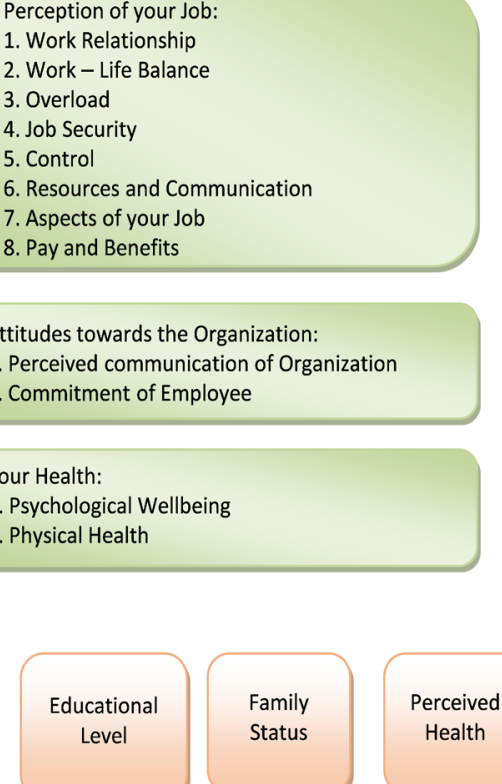


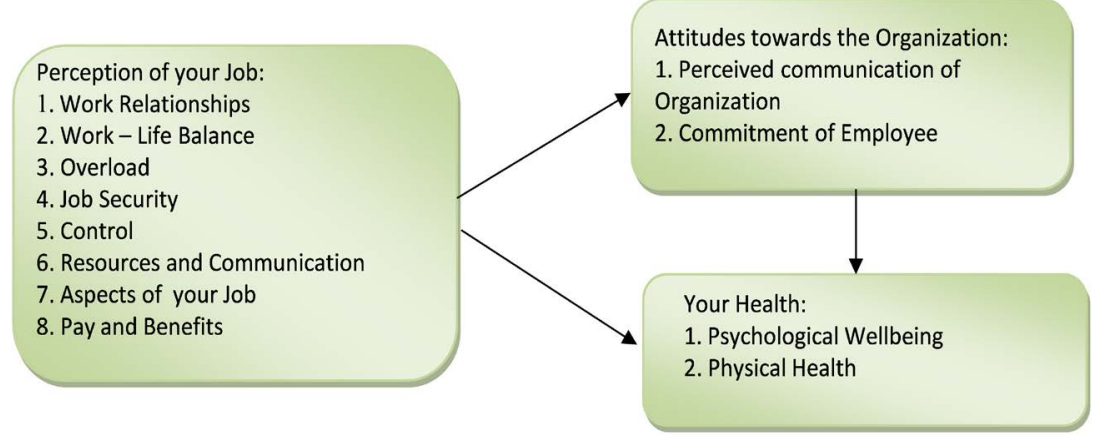

Figure 2. Faragher model of stress.

The way stressors are considered to operate is depicted in Faragher et al. (2004) as follows:

The purpose of the present study is to examine whether therapy helps the reduction of occupational stress levels in Greek women. Our main research questions are:

1) Does therapy lead to better occupational stress coping results in comparison to the absence of therapy?

2) Which psychotherapeutic approach leads to better occupational stress level reduction, Adlerian or Person Centered?

\subsection{Sample}

We collected primary data through a questionnaire based survey, conducted between October 2018 and March 2019. The questionnaire was given to 250 actively working women, aged between $25 \& 55$, of whom 178 responded and can be divided in 3 different groups: the first one includes women who have had at least 6 months of Person-Centered psychotherapy (PCA), the second group had at least 6 month of Adlerian-Individual psychotherapy (AP) and the last one has

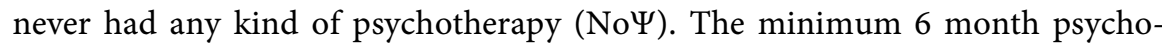
therapy quota was determined, among others, by the van Rijn, B. V. \& Wild, C. (2013) study, which showed for different approaches that within 6 months of psychotherapy there is, on average, significant measurable improvement. With regards to the average years of psychotherapy of the first 2 groups, the first group has had an average of 4.31 years of PCA, while the second one 4.10 years of AP. The first 2 groups comprised of 59 individuals each, while the $3 \mathrm{~d}$ one of 60.

\subsection{Tools/Measures}

The ASSET Questionnaire

The scaled (for Greece) ASSET (A Shortened Stress Evaluation Tool-Faragher E. B. et al., 2004) self-report questionnaire was used for this survey ${ }^{1}$. This ques-

${ }^{1}$ With the kind permission of Prof. Ioannis Nikolaou (inikol@aueb.gr) to use it and forward him the results both for processing and to be included in the larger ASSET questionnaire pool conducted by the Athens University of Economics and Business in Greece. 
tionnaire was selected among a wide variety of occupational stress questionnaires ${ }^{2}$, because it is scaled for the Greek Population, it is "validated and reliable, with proven psychometric properties", "it is constructed using items directly pertinent both to the hazards/stressors and the moderating/mediating factors likely to be found" on the stressor-strain relationship (Faragher E. B. et al., 2004: p. 191), and it is shorter than the OSI-R. Actually the ASSET questionnaire is considered a "screening" questionnaire, based on which the people scoring high on the stress factors, are then prompted to complete a much longer and detailed questionnaire, such as the OSI-R. The ASSET questionnaire comprises of a set of questions measuring the exposure of the individual to a range of common workplace stressors, also addressing the issue of perceived organizational commitment to and from the individual, and some qualitative inquiries addressing the potential existence of signs and symptoms of both physical health and psychological well-being" (Faragher E.B. et al., 2004: p. 192).

The questionnaire has been successfully tested for face, construct and convergent validity (Faragher, 2004). With regards to face validity the questions are well examined, ensuring in its construction that the language and meanings used is were confirmed to be "acceptable to all grades and types of employees" (Faragher et al., 2004: p. 193). Convergent validity was assured through a very strong positive correlation between ASSET and the General Health Questionnaire-12 (GHQ-12) (Johnson, 2001), and a very strong negative correlation between Warr's (1990) Job Satisfaction Scale. As far as construct validity is concerned, the Cronbach alpha reliability measure was used. Due to the smaller sample size in this paper, the Cronbach alphas are (mostly) lower, but still remain above the significant 0.60 threshold (Alphas $=0.63-0.85$ ).

\subsection{Procedure}

The questionnaire distribution process was diverse enough (companies, universities, random printed questionnaires on the street, psychotherapy groups, Facebook, e-mailing, college student and professors, the airport, shopping malls, etc.), to ensure that all subjects be diverse in the following areas (control variables): employment type, employment years, age, family status, presence of children (both below and above 18), education, hobbies and exercising.

The subjects received:

- An information sheet with all the relevant information on how their input questionnaires will be used;

- A consent form (explaining the use of their responses and where that use is limited;

${ }^{2}$ Considered questionnaires include the Spector and Jex (1998) "the Organizational Constraints Scale", "the Quantitative Workload Inventory", and "the Physical Symptoms Inventory", Pearlin and Schooler's (1978) "Occupational Strain”, “Occupational Stress", and "Occupational Coping” Scales, Cohen et al. (1983) "Perceived Stress Scale”, Nowack's (1990) "Stress Assessment Inventory" and "Cognitive Hardiness Scales", Roesch and Rowley (2005) "Stress Appraisal Measure”, Sarason et al. (1983) "Social Support Questionnaire", and Osipow and Spokane's (1992) \& Osipow (1991, 1998) revised "Occupational Stress Inventory" (OSI-R), Andreou (2011) "Perceived Stress Scale" (PSS). 
- The questionnaire

All subjects were assured confidentiality and anonymity (including time-related coding of their questionnaire). A research specific email

(women.work.stress@hotmail.com) was created and appended on the consent form in order for the participants to have the option to sign up to the mailing list where the progress and end results of the research can be communicated to them. This email was also used for the participants to communicate any concerns they might have throughout the research period (including potential need for psychological support after filling in their questionnaire), or their potential wish to withdraw their participation (up to one week after their questionnaire submission). Information has been held in my private computer at home, under lock and key, and once the data were analyzed and reported, the participants' answers have been deleted.

\section{Results}

For the purpose of this study the following analyses were used: Descriptive statistics, ANOVA analysis and Regression analysis. The Sorbel Test was used to check for mediation. All statistical analyses were performed using the Stata (Software for Statistics and Data Science program) software.

\subsection{Descriptive Statistics}

Care was given that the questionnaire would reach the maximum possible (within the time limits) participants, with as many methods as possible, to avoid missing a possible representative group of the Athens area.

With regards to the respondent sample, the average age of all three group participants is around 37, approximately half of the sample in each group is either married or lives together with their partner/companion (who mostly works full time-between 92\% - 97\%), and the participants who have children (married, divorced or widowed) have an average of a bit less than one child (averages 0.81 - 0.83).

More than $80 \%$ of the participants hold a bachelor degree or higher, and on average they have been working in the same job/company/role for the past 9 - 11 years, between 37 - 40 hours per week $(2-3$ hours more than contractually agreed).

Job descriptions included (Table 1) are quite diverse, both within each group, as well as the entire sample, ranging from secretarial, employee, technical, supervisory, freelance, sales, marketing, management, counselling, teaching, legal, banking, self-employed and more.

Socially, those doing psychotherapy tend to mingle socially with their colleagues more (PCA 64\%, Adlerians 75\%) than those who have never had any kind of psychotherapy (52\%) and many participants, in all three groups, tend to have

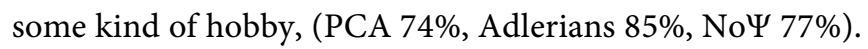

In terms of productivity (Table 2 ), those who have never had any psychothe- 
rapy score best, feeling that in the last 3 months, only $30 \%$ have been less than $80 \%$ productive at work, followed by the PCA (44\%) and the Adlerians (53\%).

The participants who have had Adlerian psychotherapy stand out in finding time to relax (61\%) versus their peers, count more smokers (37\%) and alcohol drinkers (66\%) than the other groups, but also are the most systematic in regular exercising (39\% vs $29 \%$ - 30\%) though less than $13 \%$ in all 3 approaches considers exercising a part of their routine.

As far as their perceived health is concerned, only $12 \%$ of the participants faced some significant ilness in the past 6 months (half of them belonging to the PCA group). 97\% of the respondents believe their health is good or "ok", and of those that believe their health to be bad, the majority come from the group that has not had any psychotherapy (67\% though comprised of only 4 participants out of 6). $49 \%$ of the respondents have not taken a sick leave from work in the past 3 months, reducing the average of the sample to 1.25 sick leave days; the Adlerian group apprears to be the "healthier" with $64 \%$ taking no sick leave days (vs $37 \%-47 \%$ ), while the PCA group counts the larger group of people who have taken at least 1 sick leave day in the past 3 months ( 37 vs $21 \& 12$ ). As a result $54 \%$ of the respondents have not been to the doctor in the past 3 months, again the Adlerians scoring only 21 respondents with doctor visits (vs 30 for the other 2 teams. $52 \%$ of the sample have faced a very stressful event in the past 6 months, the majority of them (46\%) belonging to the PCA group.

Table 1. Sampe distribution regarding job description/role.

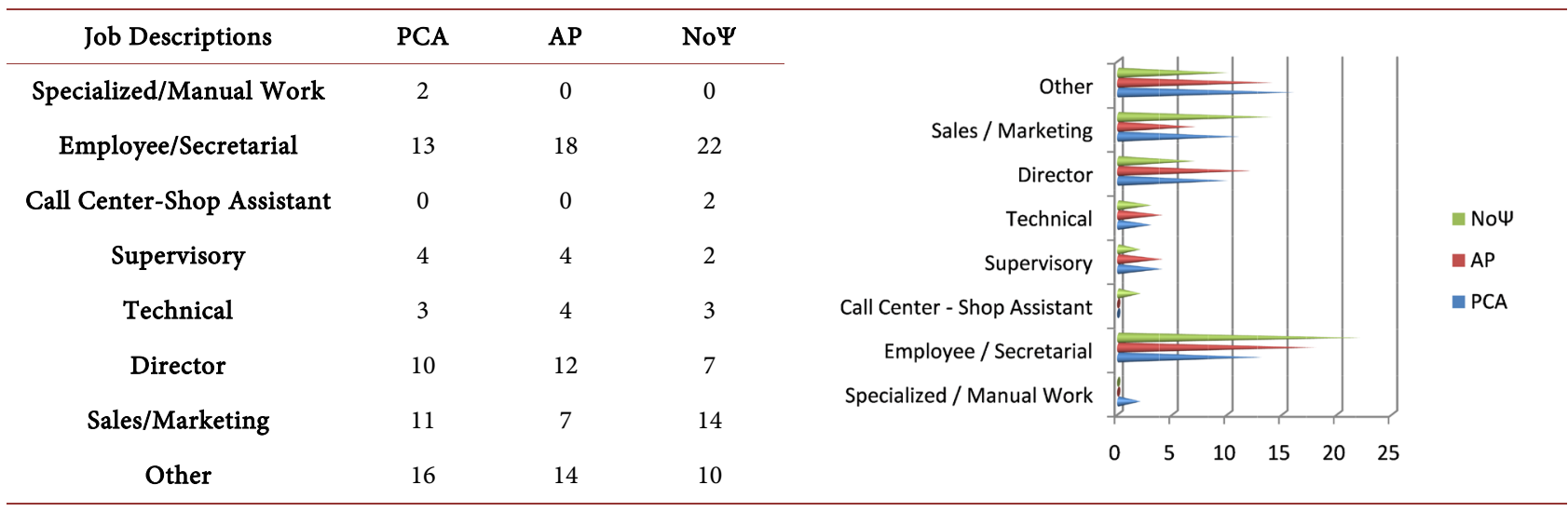

Table 2. Sample distribution regarding self perceived productivity in the previous 3 months.

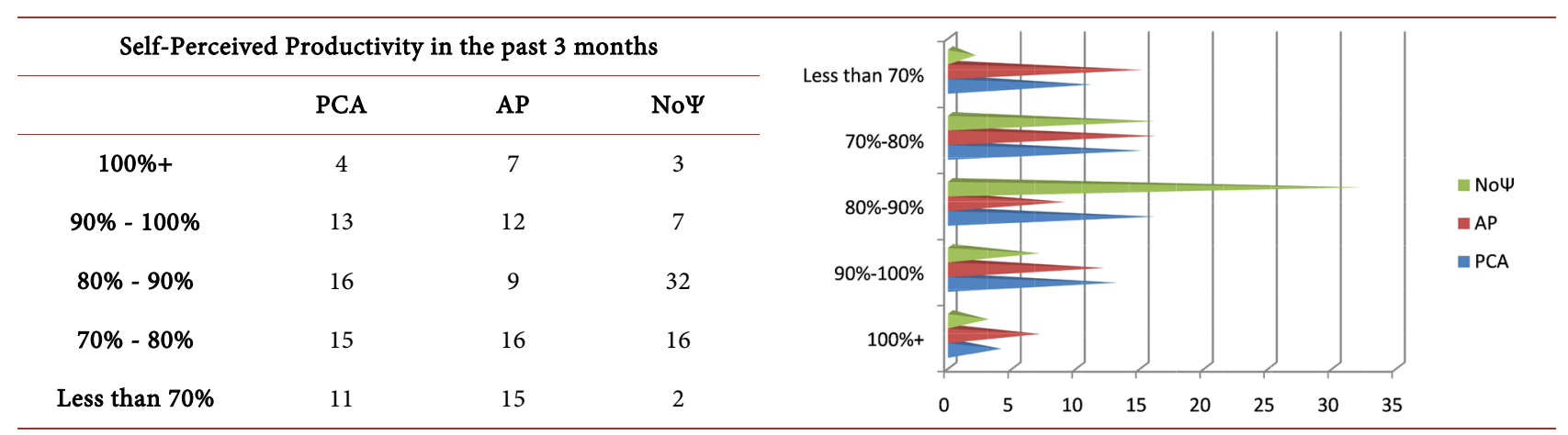




\subsection{Anova Tests}

\section{One Way ANOVA of 3 Cumulative Stress Factors vs} the 7 Control Variables

The first step to analyzing the data was to perform a one way analysis of variance (1-way ANOVA) on the 12 factors, using the following qualitative data as controls/independent variables (in parentheses the answering options of the participants):

1) Number of children (numeric);

2) Practice of regular exercise (1: never, 2: not usually, 3: sometimes, 4: frequently, 5: always);

3) Presence of stressful event(s) in the past 6 months (1: yes, 0: no);

4) Presence of a hobby (1: yes, 0: no);

5) Educational level (1: School, 2: Professional School, 3: Bachelor, 4: Master's Degree, 5: $\mathrm{PhD}$ );

6) Family Status (1: married, 2: live with partner, 3: single, 4: divorces, 5: separated, 6: widowed);

7) Perceived health (1: good, 2: ok, 3: bad).

The main statistics of the control variables can be seen in Table 3 .

Initially, each of the 3 major factors, were examined through a one-way ANOVA against every one of the control variables. Since this is a multiple comparison test, an additional Bonferroni adjustment is made to avoid an erroneous indication of statistical significance. Table 4 links the stress factor to the control variable that indicated a significant $p$-value.

In the specific sample, the control variables that affect all 3 factors are the following: the presence of a hobby, exercising (though the frequency varies) and perceived health (again the perception of the health level is not constant for all 3 factors). The presence of children (specifically 2 as opposed to none) and being single increases the stress created through the attitude towards the organization factor, while with regards to the health factor, the occurrence of stressful events in the last 6 months, tends to have its toll (education level is not supported by the Bonferroni adjustment). Again the $p$-value indicates the level of importance of each control variable.

Table 3. Anova descriptive data regarding the 7 control/independent variables.

\begin{tabular}{ccc}
\hline \multicolumn{3}{c}{ Control (Qualitative/Descriptive) Data } \\
\hline Controls: & Mean & Standard Deviation \\
\hline Children & 0.82584 & 1.01848 \\
Exercising & 3.02809 & 1.17136 \\
Stressful event in the last 6 months & 0.52247 & 0.50090 \\
Hobby & 0.78652 & 0.41092 \\
Education Level & 3.43258 & 0.81543 \\
(Marital) Status & 2.33708 & 1.41776 \\
Perception of own Health & 1.52247 & 0.56454 \\
\hline
\end{tabular}


Table 4. Anova results regarding the effect of the 7 control variables on the dependent variables.

\begin{tabular}{|c|c|c|c|c|c|c|}
\hline \multicolumn{7}{|c|}{ Normative Data Comparison } \\
\hline \multirow[t]{2}{*}{ Factors } & \multicolumn{3}{|c|}{ MEAN } & \multicolumn{3}{|c|}{ STANDARD DEVIATION } \\
\hline & $\begin{array}{l}\text { ASSET total added } \\
\text { average, divided by } \\
\text { the number of } \\
\text { questions per } \\
\text { factor in ASSET }\end{array}$ & $\begin{array}{c}\text { ASSET } \\
\text { Questionnaire } \\
\text { (9169 individuals) } \\
\text { (Faragher et al., } \\
\text { 2004) }\end{array}$ & $\begin{array}{c}\text { Greek Women } \\
\text { Sample (178 } \\
\text { individuals) }\end{array}$ & $\begin{array}{l}\text { ASSET total added } \\
\text { SD divided by } \\
\text { the nyumber of } \\
\text { questions per } \\
\text { factor in ASSET }\end{array}$ & $\begin{array}{c}\text { ASSET } \\
\text { Questionnaire } \\
\text { (9169 individuals) } \\
\text { (Faragher et al., } \\
\text { 2004) }\end{array}$ & $\begin{array}{c}\text { Greek Women } \\
\text { Sample (178 } \\
\text { individuals) }\end{array}$ \\
\hline \multicolumn{7}{|l|}{$\begin{array}{l}\text { Perception of } \\
\text { your job }\end{array}$} \\
\hline Work Relationships & $19.3 / 8=$ & 2.41 & 2.56 & $7.2 / 8=$ & 0.90 & 0.9871 \\
\hline Your Job & $12.5 / 4=$ & 3.13 & 2.9 & $4.9 / 4=$ & 1.23 & 0.73 \\
\hline Overload & $12.9 / 5=$ & 2.58 & 2.7 & $1.9 / 5=$ & 0.38 & 1.11 \\
\hline Control & $10.5 / 4=$ & 2.63 & 3 & $3.5 / 4=$ & 0.88 & 1.24 \\
\hline Job Security & $12.3 / 4=$ & 3.08 & 3.13 & $4.6 / 4=$ & 1.15 & 1.68 \\
\hline $\begin{array}{l}\text { Resources and } \\
\text { Communication }\end{array}$ & $12.3 / 4=$ & 3.08 & 2.69 & $4.3 / 4=$ & 1.08 & 1.09 \\
\hline Work-life Balance & $25.1 / 4=$ & 6.28 & 2.95 & $6.5 / 4=$ & 1.63 & 1.23 \\
\hline Pay and Benefits & $3.5 / 1=$ & 3.50 & 3.5 & $1.7 / 1=$ & 1.70 & 1.69 \\
\hline \multicolumn{7}{|l|}{$\begin{array}{l}\text { Attitudes towards } \\
\text { the Organization: }\end{array}$} \\
\hline $\begin{array}{l}\text { Perceived. } \\
\text { Commitment } \\
\text { of the Org. to the } \\
\text { Employee }\end{array}$ & $20 / 5=$ & 4.00 & 3.12 & $5.4 / 5=$ & 1.08 & 1.17 \\
\hline $\begin{array}{l}\text { Commitment of } \\
\text { Employee to the } \\
\text { Organization }\end{array}$ & $18 / 4=$ & 4.50 & 3.2 & $3.7 / 4=$ & 0.93 & 1.03 \\
\hline \multicolumn{7}{|l|}{ Your Health: } \\
\hline Physical Health & $14.2 / 6=$ & 2.37 & 2.67 & $4.1 / 6=$ & 0.68 & 1.08 \\
\hline $\begin{array}{l}\text { Psychological } \\
\text { Well-being }\end{array}$ & $24 / 11=$ & 2.18 & 2.16 & $7.6 / 11=$ & 0.69 & 0.65 \\
\hline
\end{tabular}

\subsection{One Way ANOVA of 12 Individual Stress Factors vs the 7 Control Variables}

A more elaborate analysis can be achieved by running the same one way ANOVA, with a Bonferroni adjustment for the individual sub-factors of each of the 3 major factors as shown in Table 5 below. The following table indicates the interesting $p$-values.

Overall the results of the previous ANOVA test are confirmed, and further analyzed into the specific constituents of each major category that are affected by each control variable. In the specific sample, the control variables in order of importance begin with the presence of a hobby, which affects 10 out of the 12 factors, followed by the health perception of the participants (affecting 9 factors), whether they exercise ( 6 factors), the presence of a stressful event in the past 6 
months ( 5 factors) while family status and the existence of children seem to be of lesser importance.

In a similar way, the ANOVA test is used to identify whether the presence (or absence) of psychotherapy (2 kinds, Person-Centered-PCA- and Adlerian-Adler) affects the 3 major factors and subsequently, the 12 sub-factors as shown in Table 6 .

Surprisingly, PCA is shown to have no significant effect on any of the 3 major factors; its effect can be suspected (though the significance is border line) on the "work-life balance" and "control" sub-factors. On the other hand, Adlerian psychotherapy is shown to affect significantly the "Psychological Wellbeing" sub-factor of the "Your Health" principal factor.

\subsection{Regression Analysis}

A preliminary regression of the therapy options and the control variables on the factors (both major and sub-factors) gives a more detailed view on all the existing, significant relations.

Indeed the regression verifies that person-centered psychotherapy has some effect on the sense of control and work-life balance the participants feel $(p<0.10)$ while Adlerian psychotherapy affects somewhat the psychological wellbeing of the individual (again $p<0.1$ ). Based on the above results, when one is faced with the choice between the two kinds of psychotherapy, one could choose PCA, to focus one's sense of control and work-life balance, while shift to Adlerian to focus on the overall psychological wellbeing.

The ASSET questionnaire data provide additional information, on which control factors can improve the result of each kind of psychotherapy. Regressing each kind of psychotherapy to the control factors one can identify the following separate the following factors in each treatment:

1) Adlerian Psychotherapy:

a) Attitude towards the Organization with a quite low coefficient of determination (R-squared: 0.2038 , and adjusted R-squared 0.1219):

i) Marital Status:

1) Married ( $p$-value 0.08);

2) Divorced ( $p$-value 0.041).

b) Your Health (physical and psychological) with a still low but relatively higher coefficient of determination (R-squared: 0.2930 , and adjusted R-squared 0.2204):

i) Existence of stressful event in past 6 months ( $p$-value 0.002);

ii) Education Level ( $p$-value 0.03);

iii) Marital Status: living with a partner (but not married) ( $p$-value 0.001).

c) No control variable affected the (inexistent) effect of the Adlerian psychotherapy on the "Perception of your Job".

2) Person-Centered Psychotherapy:

a) Attitude towards the Organization with a very low coefficient of determination (R-squared: 0.1724, and adjusted R-squared 0.0873):

i) Presence of a hobby ( $p$-value 0.04 );

ii) Marital Status: Married ( $p$-value 0.106). 
Table 5. Anova results of the 12 stress factors vs the control variables.

\begin{tabular}{|c|c|c|c|}
\hline Factor & Control & $p$-Value $($ Prob $>\mathrm{F})$ & Comments \\
\hline Work Relationship & Hobby & 0.0119 & \\
\hline \multirow[t]{3}{*}{ Work Relationship } & Perceived Health & 0.0042 & \\
\hline & -ok & 0.055 & \\
\hline & -bad & 0.02 & \\
\hline Work-Life Balance & Stressfull Event & 0.0835 & \\
\hline Work-Life Balance & Hobby & 0.0705 & \\
\hline \multirow[t]{2}{*}{ Work-Life Balance } & Perceived Health & 0.0024 & \\
\hline & -ok & 0.002 & \\
\hline Overload & Stressfull Event & 0.0911 & \\
\hline Overload & Hobby & 0.0709 & \\
\hline \multirow[t]{3}{*}{ Overload } & Perceived Health & 0.0017 & \\
\hline & -ok & 0.009 & \\
\hline & -bad & 0.04 & \\
\hline \multirow[t]{2}{*}{ Job Security } & Exercise & 0.073 & \\
\hline & -always & 0.051 & \\
\hline Job Security & Hobby & 0.0133 & \\
\hline \multirow[t]{3}{*}{ Job Security } & Perceived Health & 0.0265 & \\
\hline & -ok & 0.023 & \\
\hline & -bad & 0.057 & \\
\hline Resources \& Comm & Children & 0.0667 & $\begin{array}{l}\text { no such indication on } \\
\text { Bonferroni individual } \\
\text { results }\end{array}$ \\
\hline \multirow[t]{3}{*}{ Resources \& Comm } & Exercise & 0.0024 & \\
\hline & -sometimes & 0.013 & \\
\hline & -always & 0.01 & \\
\hline Resources \& Comm & Hobby & 0.1031 & \\
\hline Resources \& Comm & Partner & 0.079 & $\begin{array}{l}\text { no such indication on } \\
\text { Bonferroni individual } \\
\text { results }\end{array}$ \\
\hline \multirow[t]{3}{*}{ Resources \& Comm } & Perceived Health & 0.0004 & \\
\hline & -ok & 0.002 & \\
\hline & -bad & 0.038 & \\
\hline \multirow[t]{2}{*}{ Control } & Children & 0.0191 & \\
\hline & -5 children & 0.095 & \\
\hline
\end{tabular}




\section{Continued}

\begin{tabular}{|c|c|c|c|}
\hline Your Job & Hobby & 0.0449 & \\
\hline \multirow[t]{3}{*}{ Your Job } & Perceived Health & 0.0032 & \\
\hline & -ok & 0.031 & \\
\hline & -bad & 0.024 & \\
\hline Pay Benefits & Stressfull Event & 0.0304 & \\
\hline \multirow[t]{2}{*}{ Percv Commit. of Org } & Children & 0.0061 & \\
\hline & -2 & 0.01 & \\
\hline \multirow[t]{2}{*}{ Percv Commit. of Org } & Exercise & 0.0261 & \\
\hline & -frequently & 0.094 & \\
\hline Percv Commit. of Org & Hobby & 0.0016 & \\
\hline Percv Commit. of Org & Partner & 0.0011 & $\begin{array}{c}\text { no such indication on } \\
\text { Bonferroni individual } \\
\text { results }\end{array}$ \\
\hline Percv Commit. of Org & Perceived Health & 0.0469 & \\
\hline Commit of Employee & Exercise & 0.0967 & \\
\hline Commit of Employee & Hobby & 0.0024 & \\
\hline Commit of Employee & Partner & 0.0737 & $\begin{array}{l}\text { no such indication on } \\
\text { Bonferroni individual } \\
\text { results }\end{array}$ \\
\hline \multirow[t]{3}{*}{ Physical Health } & Exercise & 0.0028 & \\
\hline & -frequently & 0.002 & \\
\hline & -always & 0.015 & \\
\hline Physical Health & Stressfull Event & 0.0005 & \\
\hline Physical Health & Hobby & 0.0001 & \\
\hline \multirow[t]{3}{*}{ Physical Health } & Perceived Health & 0.0000 & \\
\hline & $-\mathrm{ok}$ & 0.000 & \\
\hline & -bad & 0.002 & \\
\hline \multirow[t]{2}{*}{ Psychological Wellbeing } & Exercise & 0.042 & \\
\hline & -frequently & 0.094 & \\
\hline Psychological Wellbeing & Stressfull Event & 0.0031 & \\
\hline Psychological Wellbeing & Hobby & 0.0182 & \\
\hline Psychological Wellbeing & Education Level & 0.017 & \\
\hline Psychological Wellbeing & -masters & 0.032 & \\
\hline \multirow[t]{3}{*}{ Psychological Wellbeing } & Perceived Health & 0.0000 & \\
\hline & $-\mathrm{ok}$ & 0.000 & \\
\hline & -bad & 0.068 & \\
\hline
\end{tabular}


Table 6. Anova results on the effect of Therapy on health, well-being and work-life balance.

\begin{tabular}{|c|c|c|c|}
\hline Psychotherapy & Factor & $p$-Value $($ Prob $>\mathrm{F})$ & Comments \\
\hline \multicolumn{4}{|l|}{ PCA } \\
\hline Adler & Your Health & 0.0783 & \\
\hline No Therapy (No $\Psi$ ) & Your Health & 0.0737 & \\
\hline Psychotherapy & Factor & $p$-Value $($ Prob $>\mathrm{F})$ & Comments \\
\hline \multirow[t]{2}{*}{ PCA } & Work-Life Balance & 0.0586 & \\
\hline & Control & 0.0513 & \\
\hline Adler & Psychological Wellbeing & 0.0453 & \\
\hline No Therapy (No $\Psi)$ & Psychological Wellbeing & 0.0859 & \\
\hline
\end{tabular}

b) Your Health (physical and psychological) with a still low but a little improved coefficient of determination (R-squared: 0.2593 , and adjusted R-squared 0.1832):

i) Existence of stressful event in past 6 months ( $p$-value 0.002);

ii) Presence of a hobby ( $p$-value 0.0638 );

iii) Education Level ( $p$-value 0.03$)$;

iv) Marital Status: married ( $p$-value 0.074).

c) No control variable affected the (inexistent) effect of the PCA psychotherapy on the "Perception of your Job".

The final step is to combine the statistically significant control variables that affect the important stress factors in each approach. We get the following results:

\subsection{PCA Psychotherapy}

1) Work-Life Balance:

a) We have already identified as per the specific sample of this study, that the control variables that affect Work-Life Balance in a significant way are as shown in Table 7.

b) Regressing the above control variables on work-life balance, with the addition of the presence of at least 6 months of PCA one can derive the following results:

i) PCA therapy is confirmed to affect work-life balance significantly ( $p$-value 0.059);

ii) The presence of a stressful event in the last 6 months to a person doing at least 6 months of PCA does not have a serious impact on the Work-Life Balance segment of his felt stress at work ( $p$-value 0.313 );

iii) Neither does adding a hobby to the person doing PCA ( $p$-value 0.2260 );

iv) The way a person perceives his health, when that person is doing at least 6 motnhs of PCA does have a significant impact on how that person reports his work-life balance to be (PCA $p$-value 0.07 , and perceived health $p$-value 0.055 although there is a low adjusted R-square 0.0446); 
Table 7. Factors that affect work-life balance.

\begin{tabular}{ccc}
\hline Work-Life Balance & Stressfull Event & 0.0835 \\
Work-Life Balance & Hobby & 0.0705 \\
Work-Life Balance & Perceived Health & 0.0024 \\
& -ok & 0.002 \\
\hline
\end{tabular}

v) When someone is doing at least 6 months of PCA, the perception of his health plays a significant role on his work-life balance (perceived health has a $p$-value of 0.082 , with a very low adj. R-squared: 0.0430$)$, but at the same time, the presence of a hobby does not ( $p$-value 0.371 );

vi) Finally when someone does at least 6 months of person-centered psychotherapy, if a stressfull event occurs, that person has a regular hobby and perceives his health to be ok, it is the health perception that appears to be the most important control variable ( $p$-value 0.102 ) although it is marginally significant and with a low adj. R-squared (0.0385);

vii) It should be noted that the adjusted r-squared maximizes when regressing PCA with the presence of a hobby and a good health perception (adj. r-squared 0.0430). If we add to the above control variables the presence of a stressful event, the adjusted $\mathrm{r}$-squared drops to 0.0385 . Still both figures are very low to provide any conclusive remarks;

viii) PCA therapy is confirmed to affect the sense of control significantly ( $p$-value 0.051);

ix) People who have had at least 6 months of PCA therapy, are further influenced by the presence of children, although this influence is marginally significant: only the 5 children have a $p$-value lower that $0.10(0.045)$ and a very log adjusted $r$-squared value (0.0760). Given there was only 1 respondent with 5 children, the statistic is not very dependable.

\section{Discussion}

Comparing people who have had at least 6 months of Adlerian psychotherapy to those who have had no psychotherapy at all, on their psychological wellbeing, accounting for the above control factors one can derive the following conclusions:

i) Adlerian therapy is confirmed to affect psychological wellbeing significantly ( $p$-value 0.045 , although the adj. $r$-squared is very low: 0.0256);

ii) People doing Adlerian psychotherapy do not appear to gain extra benefits from exercising in their psychological wellbeing ( $p$-value 0.349$)$, and their educational level does not have a significant influence either ( $p$-value 0.403 );

iii) However, despite their Adlerian psychotherapy, their psychological wellbeing appears to be affected by a stressful event within the last 6 months appears ( $p$-value 0.013 , again with a very low adjusted $r$-squared: 0.068$)$ ), and so does their health perception ( $p$-value 0.000 , with an adjusted $r$-squared value a bit higher (0.1465)); 
iv) When we add both stressful event and the perception of health, the health perception (0.0000 appears to influence more the psychological wellbeing of the people who do Adlerian psychotherapy, than the presence of a stress full event (0.04) though both remain quite significant (and the adjusted r-squared goes to $0.1703)$;

v) Finally, testing all the relevant (with the psychological wellbeing factor) control variables in the regression, against the respondents who have had at least 6 months to Adlerian Psychotherapy, the results remain more or less the same, with perception of health being the most significant influence (0.000) followed by the presence of a stressful event (and the adj. r-squared maximizes to a 0.20 level).

The general conclusion of this research is that psychotherapy does have some effect on the stress levels experienced by women in the workforce in Athens. Both psychotherapy approaches affect the occupational stress level of the respondents, although each in a different stress-related area.

Person-Centered psychotherapy seems to affect mainly the perception one has for one's job, and more specifically the work-life balance and job control components of this job perception, while Adlerian psychotherapy appears to affect the psychological wellbeing one has while working on one's job. Faragher, E.B. et al. (2004) mention that Job Control correlated highly with Psychological health (but not physical), suggesting that possibly the effect of both psychotherapies may be intertwined in the effects, and calculations of each stress component. Also, Karasek (1979) suggests that having low job control has a major impact on all health facets, something that reinforces the above argument, even though Faragher et al. (2004) support that job satisfaction has a higher correlation to the health component.

There is room for further investigation in understanding/evaluating the combination of the nature of each psychotherapeutic approach to the stress-related factor they appear to affect: PCA, inducing acceptance aids in how the respondent perceives her work-life balance, and her control in the job, while Adlerian Psychotherapy, which increases the encouragement of the individual (Choimes Karagianni, 1984) positively affects the psychological wellbeing of the respondent.

Still the statistics the above conclusions are based on, are not very strong, and that could be attributted to the specificity of the sample (Athens area only), and the small number of the participants (178, compared to 9,169 the ASSET questionnaire is based on). Nevertheless Adlerian statistics tend to imply a stronger relationship to the stress components than the Person-Centered ones (although as mentioned, still quite weak). Even comparing the basic normative figures between the original ASSET population and our samples, the numbers appear to have some discrepancies. This suggests that further analysis needs to be done, with a greater sample to either strengthen or abolish the aforementioned conclusions.

It would also be interesting to repeat this research in 10 years time, when the present crisis will hopefully be long gone and forgotten and see whether there was a shift in the stress perception of the people in Greece.

Also, comparing the equivalent responses of the male Athens population, 
could provide substantial results for comparison in the gender inequality gap of felt/self-reported stress.

Overall, the present study, may be used as a stepping stone in further elaborating the female stress in crisis-stricken countries (or extended to different regions in Greece, to compare how the women in each region experienced occupational stress), the effect the economic cycle may have on the occupational stress of women, how psychotherapy affects the employment stress women feel, or, if compared with an equivalent male population outcome, the difference of the felt stress between men and women in Greece, at the end of an economic crisis.

\section{Conclusion/Limitations/Future Directions}

Some limitations of this study center around the questionnaire employed and the sample used and provide opportunities for further elaboration.

With regards to the questionnaire, one needs to keep in mind that this is a preliminary questionnaire, hence it would be advisable to deepen the research in each category investigated, and especially in the 3 stress factors identified (work-life balance, control, psychological wellbeing), with more specialized questionnaires. This could help further understand specifically which aspects or subcomponents of control, work-life balance and psychological wellbeing are specifically affected by each psychotherapy approach, and better delineate the effects each psychotherapy approach has on occupational stress.

The questionnaire was built and tested some 10 - 15 years ago, based on the Cooper \& Marshall (1978) stress model, considering several other contemporaries at the time issues. Although the time that has elapsed has contributed to the verification of the validity of the questionnaire, there may be some lag in the more recent occupational stress findings, for example bullying.

Also the test is a self-reporting tool. This is compatible with the phenomenological approach of both psychotherapy approaches examined, since the purpose of this study is to identify the self-perceived stress-related improvement that each individual reports. Nonetheless there is always room for some placebo effect, especially with the individuals that "recently" started psychotherapy. This is why the 6 months minimum bar was used (Rijn, B. V. \& Wild, C., 2013), but given the non-linearity of the psychotherapeutic process/improvement and the fact that the respondents did not attend psychotherapeutic sessions targeted necessarily towards work stress, but on whichever issue they chose to tackle, that there is always room for some misrepresentation of the final results.

Moreover, the fact that the specific questionnaire "attempts to elicit self-report estimates of both the causes and effects of workplace stress", may inflate any relationship present "by common method variance-associations (correlations) between the causes and effects of stress may be over-estimated due to individuals answering all sections of the questionnaires in a set way (e.g. through having a tendency to respond positively to questions). Shared variance with a third factor may inflate the relationship (e.g. an extraneous factor may determine both the extent to which an individual experiences certain stressors and the level of stress 
they experience) (Faragher, E.B. et al., 2004: p. 199; Lyne et al., 1994).

Finally, the intentionally "simplistic" scoring method of the stress scales (simple addition of scores, without for example varying weights showing the relative importance of each factor considered) which was meant to keep the questionnaire scoring simple, begs additional evaluations, using more comprehensive/specialized scoring tools for a better and more elaborate psychometric evaluation.

With regards to the sample used, emphasis is given to the small size of the sample. Comparing the normative data of the ASSET Questionnaire to our sample, some stress factors vary significantly. This could be attributed to the specificity of the characteristics of the sample or other parameters, but it is of importance to mention that the sample of this study is $1.9 \%$ the size of the original ASSET questionnaire sample.

Furthermore, although care was given to the diversity of the group, it still remains elusive whether some specific representational groups of the Athens population might be missing. Again this may be related to the sample size concerns. It should also be added here that because the questionnaires were distributed in several random ways, the lack of a controlling environment leaves further room for inconsistencies perhaps affecting the respondent's answers.

Another issue that may limit the ability to generalize the findings of this study is the fact that this is not a longitudinal research; the respondents were approached in the fall of 2018-spring 2019, when the economic crisis was trending towards its end. As a result one may speculate that this is the peak time for the occupational stress to be measured (the individuals having undergone the entire crisis), but the opposite may as well be valid (silver-lining hope at the end of the tunnel). Given the interaction of so many factors at play, to infer cause-and-effect relationships, a longitudinal research should be employed, accounting not only for the time lag in each respondent's stress perceptions and the organizational aggregate, but also the economic situation of the country and several cultural elements.

The impact of occupational stress is well known, especially on the financial and human resources costs front; stress has been identified and studied for almost a century now, and occupational stress has been at the center point for the past 50 years. This study covered the theoretical backbone of stress, occupational stress, \& the differences in how it is experienced by women and investigated how person-centered and Adlerian psychotherapy may affect the felt occupational stress of women, using the ASSET questionnaire, on 178 women, residing/working in Athens. The results indicate that both psychotherapy approaches have an effect on the perceived occupational stress, and more specifically, that Adlerian psychotherapy influences positively the psychological wellbeing of the individual, while Person-Centered Psychotherapy has a positive effect on the perceived job control and the work life balance of the respondent. This is consistent with the nature of the psychotherapy methods (Choimes Karagiannis, I., 1984), opening the way for further investigation either towards the exact mechanisms each psychotherapy approach uses, or the overall study of work stress, on women, in Greece or after a completion of an economic crisis. 


\section{Conflicts of Interest}

The authors declare no conflicts of interest regarding the publication of this paper.

\section{References}

Adler, A. (1926). The Neurotic Constitution: Outlines of a Comparative Individualistic Psychology and Psychotherapy (Bernard Glueck and John E. Lind, Trans.). New York: Dodd, Mead, and Co. (Original Work Published 1912).

Adler, A. (1931). What Life Should Mean to You. Boston, MA: Little Brown.

Adler, A. (1959). The Practice and Theory of Individual Psychology (1920). Paterson, NJ: Littlefield, Adams.

Adler, A. (1963). Individual Psychology. Boston: Adams \& Company.

Adler, A. (1964). Social Interest: A Challenge to Mankind (Vol. 108). New York: Capricorn Books.

Adler, A. (1966). The Psychology of Power. Journal of Individual Psychology, 22, 166. https://doi.org/10.1037/h0072190

Aldwyn, C. M. (2009). Stress, Coping and Development: An Integrative Perspective. New York: Guilford Press.

Alvesson, M., \& Deetz, S. (2001). Doing Critical Management Research. London: Sage. https://doi.org/10.4135/9781849208918

American Psychological Association (APA) (2012). Recognition of Psychotherapy Effectiveness. http://www.apa.org/about/policy/resolution-psychotherapy.aspx

American Psychological Association (APA) (2013). How Stress Affects Your Health. Washington DC: APA. http://www.apa.org/helpcenter/stress-facts.pdf

American Psychological Association (APA) (2015). 2015 Annual Report. A Supplement to American Psychologist, July-August 2016, Vol. 7, No. 5.

Andreou, E., Alexopoulos, E. C., Lionis, C., Varvogli, L., Gnardellis, C., Chrousos, G. P., \& Darviri, C. (2011). Perceived Stress Scale: Reliability and Validity Study in Greece. International Journal of Environmental Research and Public Health, 8, 3287-3298. https://doi.org/10.3390/ijerph8083287

Ansbacher, H. L. (1990). Alfred Adler's Influence on the Three Leading Cofounders of Humanistic Psychology. Journal of Humanistic Psychology, 30, 45-53. https://doi.org/10.1177/002216789003000404

Antonovsky, A. (1987). Unravelling the Mystery of Health. How People Manage Stress and Stay Well. San Francisco: Jossey-Bass.

Aryee, S. (1993). Dual-Earner Couples in Singapore: An Examination of Work and Nonwork Sources of Their Experienced Burnout. Human Relations, 46, 1441-1468. https://doi.org/10.1177/001872679304601205

Bandura, A. (1977). Self-Efficacy: Toward a Unifying Theory of Behavioral Change. Psychological Review, 84, 191-215. https://doi.org/10.1037/0033-295X.84.2.191

Bandura, A. (1982). Self-Efficacy Mechanism in Human Agency. American Psychology, $44,175-184$.

Barnett, R. C., \& Brennan, R. T. (1997). Change in Job Conditions, Change in Psychological Distress, and Gender: A Longitudinal Study of Dual-Earner Couples. Journal of Organizational Behavior, 18, 253-274.

https://doi.org/10.1002/(SICI)1099-1379(199705)18:3<253::AID-JOB800>3.0.CO;2-7 
Beena, C., \& Poduval, P. R. (1992). Gender Differences in Work Stress of Executives. Psychological Studies, 37, 109-113.

Bekker, M. H., De Jong, P. F., Zijlstra, F. R., \& van Landeghem, B. A. (2000). Combining Care and Work: Health and Stress Effects in Male and Female Academics. International Journal of Behavioral Medicine, 7, 28-43. https://doi.org/10.1207/S15327558IJBM0701_3

Blechman, E. A., \& Brownell, K. D. (1998). Behavioral Medicine and Women. New York: Guilford Press.

Bliese, P. D., \& Britt, T. W. (2001). Social Support, Group Consensus and Stressor-Strain Relationships: Social Context Matters. Journal of Organizational Behavior: The International Journal of Industrial, Occupational and Organizational Psychology and Behavior, 22, 425-436. https://doi.org/10.1002/job.95

Buckley, W. (1967). Sociology and Modern Systems Theory. Englewood Cliffs, NJ: Prentice Hall.

Burke, R., \& Belcourt, M. L. (1974). Managerial Role Stress and Coping Responses. Journal of Business Administration, 5, 55-68.

Campbell, L. F., Norcross, J. C., Vasquez, M. J., \& Kaslow, N. J. (2013). Recognition of Psychotherapy Effectiveness: The APA Resolution. Psychotherapy, 50, 98. https://doi.org/10.1037/a0031817

Carlsen, S., \& Elm Larsen, J. (1993). The Equality Dilemma-Reconciling Working Life and Family Life, Viewed in an Equality Perspective: The Danish Example (The Danish Equal Status Council). Copenhagen: Munksgaard International.

Carlson, D. S., \& Perrewé, P. L. (1999). The Role of Social Support in the Stressor-Strain Relationship: An Examination of Work-Family Conflict. Journal of Management, 25, 513-540. https://doi.org/10.1177/014920639902500403

Cartwright, S., \& Cooper, C. (1997) Managing Workplace Stress. Thousand Oaks, CA: Sage.

Cavanaugh, M. A., Boswell, W. R., Roehling, M. V., \& Boudreau J. W. (2000). An Empirical Examination of Self-Reported Work Stress among U.S. Managers. Journal of Applied Psychology, 85, 65-74. https://doi.org/10.1037/0021-9010.85.1.65

Chen, W.-Q., Siu, O.-L., Lu, J.-F., Cooper, C. L., \& Phillips, D. R. (2009). Work Stress and Depression: The Direct and Moderating Effects of Informal Social Support and Coping. Stress Health, 25, 431-442. https://doi.org/10.1002/smi.1263

Chesney, M. A., \& Ozer, E. M. (1995). Women and Health: In Search of a Paradigm. Women's Health: Research on Gender, Behavior, and Policy, 1, 3-26.

Choimes Karagianni, I. (1984). Acceptance vs Encouragement Group Approaches Attribute within Café-Ecole Model. PhD Dissertation, San Rafael, CA: Columbia Pacific University.

Cohen, S., Kamarck, T., \& Mermelstein, R. (1983). A Global Measure of Perceived Stress. Journal of Health and Social Behavior, 24, 386-396. https://doi.org/10.2307/2136404

Cohen, S., Kessler, R. C., \& Underwood Gordong, L. (1997). Measuring Stress: A Guide for Health and Social Scientists. New York: Oxford University Press Inc.

Confederation of British Industry (1998). Life on the Edge. Confederation of British Industry Magazine, July-August, 1998.

Conger, R. D., Lorenz, F. O., Elder, G. H., \& Simons, R. L. (1993). Husband and Wife Differences in Response to Undesirable Life Events. Journal of Health and Social Behavior, 34, 71-88. https://doi.org/10.2307/2137305

Cooper, C. L., \& Dewe, P. (2004). Stress. A Brief History. Oxford: Blackwell. https://doi.org/10.2307/3660781 
Cooper, C. L., \& Marshall, J. (1978). Understanding Executive Stress. London: The Macmillan Press Ltd. https://doi.org/10.1007/978-1-349-03030-9

Cooper, C. L., Philip, D. J., \& O’Driscoll, M. P. (2001). Organizational Stress. Thousand Oaks, CA: Sage Publication.

Cooper, M., O’Hara, M., Schmid, P., \& Wyatt, G. (2007). The Handbook of Person-Centered Psychotherapy and Counselling. New York: Palgrave Macmillan.

Cox, T., \& McKay, C. (1981). A Transactional Approach to Occupational Research. In E. N. Corlett, \& J. Richardson (Eds.), Stress, Work Design and Productivity (pp. 91-115). New York: Jon Wiley.

Cummings, T. G., \& Cooper, C. L. (1979). A Cybernetic Framework for Studying Occupational Stress. Human Relations, 32, 395-418. https://doi.org/10.1177/001872677903200504

Danziger, K. (1997). Naming the Mind: How Psychology Found Its Language. London: Sage.

Decker, P. J., \& Borgen, F. H. (1993). Dimensions of Work Appraisal: Stress, Strain, Coping, Job Satisfaction, and Negative Affectivity. Journal of Counselling Psychotherapy, 40, 470-478. https://doi.org/10.1037/0022-0167.40.4.470

Dewe, P. J. (1991). Primary Appraisal, Secondary Appraisal and Coping Their Role Is Stressful Work Encounters. Journal of Occupational Psychology, 64, 331-351. https://doi.org/10.1111/j.2044-8325.1991.tb00564.x

Eckenrode, J., \& Gore, S. (1990). Stress between Work and Family. New York: Plenum. https://doi.org/10.1007/978-1-4899-2097-3

Ekvall, G., Frankenhaeuser, M., \& Parr, D. (1994). Leadership Style and Leadership Stress. A Study of Male and Female Managers in Public Dental Health Care (Report No. 1). Stockholm: Institute for Research, Business, and Work Life Issues.

Epstein, S., \& Meier, P. (1989). Constructive Thinking: A Broad Coping Variable with Specific Components. Journal of Personality and Social Psychology, 57, 332. https://doi.org/10.1037/0022-3514.57.2.332

Faragher, E. B., Cooper, C. L., \& Cartwright, S. (2004). A Shortened Stress Evaluation Tool Asset. Stress and Health, 20, 189-201. https://doi.org/10.1002/smi.1010

Feltham, C. (1997). Which Psychotherapy? Leading Exponents Explain Their Differences. London: Sage.

Fiedler, F. E. (1950). A Comparison of Therapeutic Relationships in Psychoanalytic, Nondirective and Adlerian Therapy. Journal of Consulting Psychology, 14, 436. https://doi.org/10.1037/h0054624

Fineman, S. (2003). Understanding Emotion at Work. London: Sage.

Fisher, C. D., \& Gittelson, R. (1983). A Meta-Analysis of the Correlates of Role Conflict and Ambiguity. Journal of Applied Psychology, 68, 320-333.

https://doi.org/10.1037/0021-9010.68.2.320

Frankenhaeuser, M., Lundberg, U., Fredrikson, M., Melin, B., Tuomisto, M., Myrsten, A.-L., Hedman, M., Bergman-Losman, B., \& Wallin, L. (1989). Stress on and off the Job as Related to Sex and Occupational Status in White-Collar Workers. Journal of Organizational Behavior, 10, 321-346. https://doi.org/10.1002/job.4030100404

French, J. R., Caplan, R. D., \& Van Harrison, R. (1982). The Mechanisms of Job Stress and Strain (Vol. 7). Chichester, New York: J. Wiley.

Friedman, M., \& Rosenman, R. (1974). Type a Behavior and Your Heart. New York: Knopf.

Gibbard, I., \& Hanley, T. (2008). A Five-Year Evaluation of the Effectiveness of Person-Centred Counselling in Routine Clinical Practice in Primary Care. Counselling 
and Psychotherapy Research, 8, 215-222. https://doi.org/10.1080/14733140802305440

Goldstein, K. (1939). The Organism. New York: American Book.

Goleman, D. (1996). Emotional Intelligence: Why It Can Matter More than IQ. London: Bloomsbury.

Greenglass, E. R., Pantony, K. L., \& Burke, R. J. (1988). A Gender-Role Perspective on Role Conflict, Work Stress and Social Support [Special Issue: Work and Family]. Journal of Social Behavior and Personality, 3, 317-328.

Greenhaus, J. H., \& Beutell, N. J. (1985). Sources of Conflict between Work and Family Roles. Academy of Management Review, 10, 76-88. https://doi.org/10.5465/amr.1985.4277352

Gutek, B. A., Searle, S., \& Klepa, L. (1991). Rational versus Gender Role Explanations for Work-Family Conflict. Journal of Applied Psychology, 76, 560-568. https://doi.org/10.1037/0021-9010.76.4.560

Hall, E. M. (1990). Women's Work: An Inquiry into the Health Effects of Invisible and Visible Labor. Doctoral Dissertation, Stockholm: Karolinska Institute.

Hayes, C. T., \& Weathington, B. L. (2007). Optimism, Stress, Life Satisfaction, and Job Burnout in Restaurant Managers. The Journal of Psychology, 141, 565-579. https://doi.org/10.3200/JRLP.141.6.565-580

Haynes, S. G., \& Feinleib, M. (1980). Women, Work and Coronary Heart Disease: Prospective Findings from the Framingham Heart Study. American Journal of Public Health February, 70, 133-141. https://doi.org/10.2105/AJPH.70.2.133

Health and Safety Executive (HSE) (2000). Organisational Interventions for Work Stress-A Risk Management Approach (CRR286/2000).

Henkelman, J., \& Paulson, B. (2006). The Client as Expert: Researching Hindering Experiences in Counselling. Counselling Psychology Quarterly, 19, 139-150. https://doi.org/10.1080/09515070600788303

Hinkle, L. E. Jr. (1973). The Concept of "Stress" in the Biological and Social Sciences. Science, Medicine and Man, 1, 31-48.

Horney, K. (1951). Neurosis and Human Growth: The Struggle toward Self-Realization. New York: Routledge. https://doi.org/10.4324/9781315010526

Industrial Society (2001). Managing Best Practice, Occupational Stress Report No. 83 (pp. 4-23). London: Industrial Society.

Jick, T. D., \& Mitz, L. F. (1985). Sex Differences in Work Stress. Academy of Management Review, 10, 408-420. https://doi.org/10.5465/amr.1985.4278947

Johnson, S. J. (2001). Occupational Stress among Social Workers and Administration Workers within a Social Services Department. Unpublished M.Sc. Dissertation, Manchester: University of Manchester Institute of Science and Technology.

Johnson, S., \& Cooper, C. (2003). The Construct Validity of the ASSET Stress Measure. Stress and Health, 19, 181-185. https://doi.org/10.1002/smi.971

Kahn, R. L. (1991). The Forms of Women's Work. In M. Frankenhaeuser, U. Lundberg, \& M. A. Chesney (Eds.), Women, Work and Health, Stress and Opportunities (pp. 65-83). New York: Plenum Press. https://doi.org/10.1007/978-1-4615-3712-0_4

Kahn, R. L., \& Byosiere, P. (1992). Stress in Organizations. In M. D. Dunnette (Ed.), Handbook of Industrial and Organizational Psychology (pp. 571-648). Chicago, IL: Rand McNally.

Kahn, R. L., Wolfe, D. M., Quinn, R. P., Snoek, J. D., \& Rosenthal, R. A. (1964). Organizational Stress: Studies in Role Conflict and Ambiguity. New York: Wiley.

Kalogeropoulou, M., \& Papathanasopoulou, E. (2013). The Impact of the Economic Crisis 
on the Mental Health of Nurses: A Pilot Study. Archives of Hellenic Medicine, 30, 587-594.

Kandel, D. B., Davies, M., \& Raveis, V. H. (1985). The Stressfulness of Daily Social Roles for Women-Marital, Occupational and Household Roles. Journal of Health and Social Behavior, 26, 64-78. https://doi.org/10.2307/2136727

Karasek, R. A. (1979). Job Demands, Job Decision Latitude, and Mental Strain: Implications for Job Redesign. Administrative Science Quarterly, 24, 285-308. https://doi.org/10.2307/2392498

Kessler, R. C., McLeod, J. D., \& Wethington, E. (1985). The Costs of Caring: A Perspective on the Relationship between Sex and Psychological Distress. In Social Support: Theory, Research and Applications (pp. 491-506). Dordrecht: Springer. https://doi.org/10.1007/978-94-009-5115-0_25

Kobasa, S. C. (1982). The Hardy Personality: Toward a Social Psychology of Stress and Health. In J. Suls, \& G. Sanders (Eds.), Social Psychology of Health and Illness (pp. 3-32). Hillsdale, NJ: Erlbaum.

Kubie, L. S., \& Frank, J. D. (1961). Persuasion and Healing: A Comparative Study of Psychotherapy. The Journal of Nervous and Mental Disease, 133, 561-566. https://doi.org/10.1097/00005053-196112000-00018

Kugelmann, R. (1992). Stress: The Nature and History of Engineered Grief. Westport: Praeger.

Lambert, S. J. (1991). The Combined Effects of Job and Family Characteristics on the Job Satisfaction, Job Involvement, and Intrinsic Motivation of Men and Women Workers. Journal of Organizational Behavior, 12, 341-363. https://doi.org/10.1002/job.4030120408

Lazarus, R. S. (1966). Psychological Stress and the Coping Process. New York: McGraw Hill.

Lazarus, R. S. (1981). The Stress and Coping Paradigm. In C. Eisdorfer, D. Cohen, A. Kleinman, \& P. Maxim (Eds.), Models for Clinical Psychopathology (pp. 177-214). New York: Spectrum.

Lazarus, R. S. (1990). Theory-Based Stress Measurement. Psychological Inquiry, 1, 3-13. https://doi.org/10.1207/s15327965pli0101_1

Lazarus, R. S. (1991). Emotions and Adaptation. New York: Oxford University Press.

Lazarus, R. S. (1993). From Psychological Stress to the Emotions: A History of Changing Outlooks. Annual Review of Psychology, 44, 1-22.

https://doi.org/10.1146/annurev.ps.44.020193.000245

Lazarus, R. S., \& Folkman, S. (1984). Stress, Appraisal, and Coping. New York: Springer.

Lazarus, R. S., \& Launier, R. (1978). Stress-Related Transactions between Person and Environment. In L. A. Pervin, \& M. Lewis (Eds.), Perspectives in Interactional Psychology (pp. 287-327). New York: Plenum. https://doi.org/10.1007/978-1-4613-3997-7_12

Lazarus, R. S., Deese, J., \& Osler, S. F. (1952). The Effects of Psychological Stress upon Performance. Psychology Bulletin, 49, 293-317. https://doi.org/10.1037/h0061145

Lee, S. Y., \& Brand, J. L. (2005). Effects of Control over Office Workspace on Perceptions of the Work Environment and Work Outcomes. Journal of Environmental Psychology, 25, 323-333. https://doi.org/10.1016/j.jenvp.2005.08.001

Levenson, H., Hirschfeld, A., \& Dzubay, B. (2010). Recent Life Events and Accidents: The Role of Sex Differences. Journal of Human Stress, 9, 4-11.

https://doi.org/10.1080/0097840X.1983.9935019 
Lewin-Epstein, N. (1989). Work Characteristics and Ill Health: Gender Differences in Israel. Work and Occupations, 16, 80-104.

https://doi.org/10.1177/0730888489016001005

Li, J., Riedel, N., Barrech, A., Herr, R. M., Aust, B., Mörtl, K., Angerer, P. et al. (2017). Nine-Year Longitudinal Psychosocial and Mental Outcomes of a Stress Management Intervention at Work Using Psychotherapeutic Principles. Psychotherapy and Psychosomatics, 86, 113-115. https://doi.org/10.1159/000451028

Lumsden, D. P. (1981). Is the Concept of "Stress" of Any Use, Any More? In D. Randall (Ed.), Contributions to Primary Prevention in Medical Health: Working Papers (pp. 213-243). Toronto: Toronto National Office Canadian Mental Health Association.

Lundberg, U., Mårdberg, B., \& Frankenhaeuser, M. (1994). The Total Workload of Male and Female White Collar Workers as Related to Age, Occupational Level, and Number of Children. Scandinavian Journal of Psychology, 35, 315-327. https://doi.org/10.1111/j.1467-9450.1994.tb00956.x

Lyne, K. D., Barrett, P. T., Williams, C., \& Coley, K. (1994). A Psychometric Evaluation of the Occupational Stress Indicator. Journal of Occupational and Organizational Psychology, 73, 195-127. https://doi.org/10.1348/096317900166985

MacLennan, N. (1996). Counselling for Managers. Aldershot: Gower Publishing Company.

Maddi, S. R., \& Kobasa, S. C. (1984). The Hardy Executive: Health under Stress. Pacific Grove, CA: Brooks/Cole.

Mäkikangas, A., \& Kinnunen, U. (2003). Psychosocial Work Stressors and Well-Being: Self-Esteem and Optimism as Moderators in a One-Year Longitudinal Sample. Personality and Individual Differences, 35, 537-557. https://doi.org/10.1016/S0191-8869(02)00217-9

Makin, P. J., Cooper, C. L., \& Cox, C. (2000). Organizations and the Psychological Contract. Leicester: British Psychological Society Books.

Maslow, A. (1943). A Theory of Human Motivation. Psychological Review, 50, 370-396. https://doi.org/10.1037/h0054346

Mason, J. W. (1975). A Historical View of the Stress Field. Journal of Human Stress, 1, 6-27. https://doi.org/10.1080/0097840X.1975.9940399

Matheny, K. B., Gfroerer, C. A., \& Harris, K. (2000). Work Stress, Burnout, and Coping at the Turn of the Century: An Individual Psychology Perspective. Journal of Individual Psychology, 56, 74-87.

McGarth, J. E. (1987). Stress and Behavior in Organizations. In M. D. Dunnette (Ed.), Handbook of Industrial and Organizational Psychology (pp. 1351-1395). Chicago, IL: Rand McNally.

Mearns, D., \& Cooper, M. (2005). Working at Relational Depth in Counselling and Psychotherapy. London: Sage.

Miller, P., \& Rose, N. (2008). Governing the Present. Administering Economic, Social and Personal Life. Cambridge: Polity Press.

Newton, T. J., Handy, J., \& Fineman, S. (1995). "Managing” Stress. Emotion and Power at Work. London: Sage.

Norcross, J. C. (1990). An Eclectic Definition of Psychotherapy. In J. K. Zeig, \& W. M. Munion (Eds.), What Is Psychotherapy? Contemporary Perspectives (pp. 218-220). San Francisco, CA: Jossey-Bass.

Nowack, K. M. (1990). Initial Development of an Inventory to Assess Stress and Health Risk. American Journal of Health Promotion, 4, 173-180.

https://doi.org/10.4278/0890-1171-4.3.173 
Ntelézos, K., Méntziou, E., Koútou, A., Konómi, K., \& kai Nestorídou, A. (2014). Dierévnisi ekdílosis ergasiakoú stress se período oikonomikís krísis sto dioikitikó prosopikó tou Technologikoú Ekpaideftikoú Idrýmatos Athína. Periencheiritikí Nosileftikí, tómos 1 , téfchos 2

O’Driscoll, M. P., \& Cooper, C. L. (1996). Sources and Management of Excessive Stress and Burnout. In P. Warr (Ed.), Psychology at Work (pp. 166-197). London: Penguin.

ODriscoll, M. P., Ilgen, D. R., \& Hildreth, K. (1992). Time Devoted to Job and Off-Job Activities, Interrole Conflict, and Affective Experiena. Journal of Applied Psychology, 77, 212-219. https://doi.org/10.1037/0021-9010.77.3.272

Orr, E., \& Westman, M. (1990) Does Hardiness Moderate Stress, and How? A Review. In M. Rosenbaum (Ed.), Learned Resourcefulness: On Coping Skills, Self-Control, and Adaptive Behavior (pp. 64-94). New York: Springer.

Orth-Gomer, K., Wenger, N., \& Chesney, M. (1998). Women, Stress and Heart Disease. Mahwah, NJ: Erlbaum. https://doi.org/10.4324/9781410604538

Osipow, S. H. (1991). Developing Instruments for Use in Counseling. Journal of Counseling and Development, 70, 322-326. https://doi.org/10.1002/j.1556-6676.1991.tb01605.x

Osipow, S. H. (1998). Occupational Stress Inventory-Revised Edition (OSI-R) Professional Manual. Odessa, FL: Psychological Assessment Resources.

Osipow, S. H., \& Spokane, A. (1992). Occupational Stress Inventory: Manual: Research Version. Lutz: Psychological Assessment Resources, Incorporated.

Papaïoánnou, E., Kaddá, A., \& kai Frankiadáki, E. (2018). Ergasiakó stress kai epangelmatikí exouthénosi se período oikonomikís krísis ston idiotikó toméa. I epídrasí tous stin apódosi tou prosopikoú kai stin kathimerinótitá tou. Patra: Hellenic Open University. https://apothesis.eap.gr/bitstream/repo/38853/1/\%ce\%94\%ce\%95_evanthiapapaioanno u.pdf

Parkes, K. P. (1990). Coping, Negative Affectivity, and the Work Environment: Additive and Interactive Predictors of Mental Health. Journal of Applied Psychology, 75, 399-409. https://doi.org/10.1037/0021-9010.75.4.399

Parkes, K. R. (1991). Locus of Control as Moderator: An Explanation for Additive versus Interactive Findings in the Demand-Discretion Model of Work Stress? British Journal of Psychology, 82, 291-312. https://doi.org/10.1111/j.2044-8295.1991.tb02401.x

Pearlin, L. I., Meneghan, E. G., Lieberman, M. A., \& Mullan, J. T. (1981). The Stress Process. Journal of Health and Social Behavior, 22, 337-356. https://doi.org/10.2307/2136676

Pearlin, L., \& Schooler, C. (1978). The Structure of Coping. Journal of Health and Social Behaviour, 19, 2-21. https://doi.org/10.2307/2136319

Peck, J. H. (1985). Working Wives 1 Working Husbands. Beverly Hills, CA: Sage.

Revenson, T. A. (1997). Wanted: A Wider Lens for Coping Research. Journal of Health Psychology, 2, 164-165. https://doi.org/10.1177/135910539700200209

Rijn, B. V., \& Wild, C. (2013). Humanistic and Integrative Therapies for Anxiety and Depression: Practice-Based Evaluation of Transactional Analysis, Gestalt, and Integrative Psychotherapies and Person-Centered Counseling. Transactional Analysis Journal, 43, 150-163. https://doi.org/10.1177/0362153713499545

Roesch, S. C., \& Rowley, A. A. (2005). Evaluating and Developing a Multidimensional, Dispositional Measure of Appraisal. Journal of Personality Assessment, 85, 188-196. https://doi.org/10.1207/s15327752jpa8502_11

Rogers, C. (1951). Client-Centered Therapy: Its Current Practice, Implications and Theory. London: Constable. 
Rogers, C. (1957). The Necessary and Sufficient Conditions of Therapeutic Personality Change. Journal of Consulting Psychology, 21, 95-103. https://doi.org/10.1037/h0045357

Rogers, C. R. (1942). Counseling and Psychotherapy. Cambridge, MA: Riverside Press.

Rogers, C. R. (1959). A Theory of Therapy, Personality, and Interpersonal Relationships: as Developed in the Client-Centered Framework (Vol. 3, pp. 184-256). New York: McGraw-Hill.

Rogers, C. R. (1967). Carl R. Rogers. In G. B. Boring, \& G. Lindzey (Eds.), A History of Psychology in Autobiography (Vol. 5, pp. 341-384). New York: Appleton-Century-Crofts. https://doi.org/10.1037/11579-013

Rogers, C. R. (1995). A Way of Being. New York: Houghton Mifflin Harcourt.

Rose, N. (1990). Governing the Soul: The Shaping of the Private Self. London: Routlegde.

Rose, N. (1996). Inventing Ourselves. Psychology, Power, and Personhood. London: Routledge. https://doi.org/10.1017/CBO9780511752179

Rosenbaum, M. (1990). Learned Resourcefulness: On Coping Skills, Self-Control, and Adaptive Behavior. New York: Springer.

Ru Hsu, Y. (2011). Work-Family Conflict and Job Satisfaction in Stressful Working Environments: The Moderating Roles of Perceived Supervisor Support and Internal Locus of Control. International Journal of Manpower, 32, 233-248. https://doi.org/10.1108/01437721111130224

Sarason, I. G., Levine, H. M., Basham, R. B., \& Sarason, B. R. (1983). Assessing Social Support: The Social Support Questionnaire. Journal of Personality and Social Psychology, 44, 127. https://doi.org/10.1037/0022-3514.44.1.127

Sarídi, M., Karrá, A., \& kai Souliótis, K. (2016). Ergasiakó stress kai epangelmatíes ygeías se período oikonomikís krísis. Archives of Hellenic Medicine, 33, 73-83.

Scheier, M. F., \& Carver, C. S. (1987). Dispositional Optimism and Physical Well-Being: The Influence of Generalized Outcome Expectancies on Health. Journal of Personality, 55, 169-210. https://doi.org/10.1111/j.1467-6494.1987.tb00434.x

Selye, H. (1974). Stress without Distress. Philadelphia, PA: Lippincott.

Selye, H. (1976). Stress in Health and Disease. Oxford: Buttersworth.

Siegrist, J. (1996). Adverse Health Effects of High Effort/Low Reward Conditions at Work. Journal of Occupational Health Psychology, 1, 27-43.

https://doi.org/10.1037/1076-8998.1.1.27

Smelser, N. J. (1963). Theory of Collective Behavior. New York: The Free Press. https://doi.org/10.1037/14412-000

Smith, M. L., \& Glass, G. V. (1977). Meta-Analysis of Psychotherapy Outcome Studies. American Psychologist, 32, 752. https://doi.org/10.1037/0003-066X.32.9.752

Snyder, C. R., Harris, C., Anderson, J. R., Holleran, S. A., Irving, L. M. et al. (1991). The Will and the Ways: Development and Validation of an Individual Difference Measure of Hope. Journal of Personality and Social Psychology, 60, 570-585.

https://doi.org/10.1037/0022-3514.60.4.570

Somerfield, R. (1997). The Future of Coping Research as We Know It: A Response to Commentaries. Journal of Health Psychology, 2, 173-183.

https://doi.org/10.1177/135910539700200214

Sorensen, G., Jacobs, D. R. Jr., Pirie, P., Folsom, A., Leupker, R., \& Gillum, R. (1987). Relationships among Type a Behavior, Employment Experiences, and Gender: The Minnesota Heart Survey. Journal of Behavioral Medicine, 10, 323-336.

https://doi.org/10.1007/BF00846473 
Spector, P. E., \& Jex, S. M. (1998). Development of Four Self-Report Measures of Job Stressors and Strain: Interpersonal Conflict at Work Scale, Organizational Constraints Scale, Quantitative Workload Inventory, and Physical Symptoms Inventory. Journal of Occupational Health Psychology, 3, 356-367. https://doi.org/10.1037/t07343-000

Speierer, G. W. (1998). Psychopathology According to the Differential Incongruence Model. In L. S. Greenberg, J. C. Watson, \& G. Lietaer (Eds.), Handbook of Experiential Psychotherapy (pp. 410-427). New York: Guilford Press.

Spicer, J. (1997). Systems Analysis of Stress and Coping: A Testing Proposition. Journal of Health Psychology, 2, 173-183. https://doi.org/10.1177/135910539700200211

Spielberg, C. (1972). Anxiety as an Emotional State. In Spielberg (Ed.), Anxiety: Current Trends in Theory and Research (Vol. 1, pp. 23-46). New York: Academic Press. https://doi.org/10.1016/B978-0-12-657401-2.50009-5

Statistic Brain Research Institute (2015). Stress Statistics. http://www.statisticbrain.com/stress-statistics/Spector

Statistics Sweden (1990). Women and Men in Sweden: Equality of the Sexes.

Stawski, R. S., Almeida, D. M., Lachman, M. E., Tun, P. A., \& Rosnick, C. B. (2010). Fluid Cognitive Ability Is Associated with Greater Exposure and Smaller Reactions to Daily Stressors. Psychology and Aging, 25, 330. https://doi.org/10.1037/a0018246

Stiles, W. B., Barkham, M., Mellor-Clark, J., \& Connell, J. (2008). Effectiveness of Cognitive-Behavioural, Person-Centred, and Psychodynamic Therapies in UK Primary-Care Routine Practice: Replication in a Larger Sample. Psychological Medicine, 38, 677-688. https://doi.org/10.1017/S0033291707001511

Tetrick, L., \& LaRocco, J. (1987). Understanding, Predictions and Control as Moderators of the Relationships between Perceived Stress, Satisfaction and Psychological Well-Being. Journal of Applied Psychology, 72, 538-543. https://doi.org/10.1037/0021-9010.72.4.538

Tuten, T. L., \& Neidermeyer, P. E. (2004). Performance, Satisfaction and Turnover in Call Centers: The Effects of Stress and Optimism. Journal of Business Research, 57, 26-34. https://doi.org/10.1016/S0148-2963(02)00281-3

Väänänen, A., Anttila, E., Turtiainen, J., \& Varje, P. (2012). Formulation of Work Stress in 1960-2000: Analysis of Scientific Works from the Perspective of Historical Sociology. Social Science \& Medicine, 75, 784-794. https://doi.org/10.1016/j.socscimed.2012.04.014

van Drunen, P., van Strien, P. J., \& Haas, E. (2004). Work and Organization. In J. Jansz, \& P. van Drunen (Eds.), A Social History of Psychology (pp. 129-164). Oxford: Blackwell.

Waltz, M. E. (2016). The Efficacy of a Stress Management and Self-Care Training on Student Teachers' Stress Levels. Doctoral Dissertation.

Warner, M. S. (2005). A Person-Centered View of Human Nature, Wellness, and Psychopathology. In Person-Centred Psychopathology (pp. 91-109). Ross-on-Wye: PCCS Books.

Warr, P. (1990). The Measurement of Well-Being and Other Aspects of Mental Health. Journal of Occupational Psychology, 63, 193-210. https://doi.org/10.1111/j.2044-8325.1990.tb00521.x

Watkins, C. E. (1986). A Research Bibliography on Adlerian Psychological Theory. Individual Psychology, 42, 124.

Watson, D., \& Clark, L. A. (1984). Negative Affectivity: The Disposition to Experience Aversive Emotional States. Psychological Bulletin, 96, 465.

https://doi.org/10.1037/0033-2909.96.3.465 
Watts, R. E. (1996). Social Interest and the Core Conditions: Could It Be That Adler Influenced Rogers? The Journal of Humanistic Education and Development, 34, 165-170. https://doi.org/10.1002/j.2164-4683.1996.tb00342.x

Watts, R. E. (1998). The Remarkable Parallel between Rogers's Core Conditions and Adler's Social Interest. Journal of Individual Psychology, 54, 4-9.

Wedding, D., \& Corsini, R. J. (2013). Current Psychotherapies. Boston, MA: Cengage Learning.

White, M. (1957). Social thought in America: The Revolt against Formalism. Boston, MA: Beacon Press.

WHO (2015). Stress at the Workplace. http://www.who.int

Williams, R. B., Barefoot, J. C., Blumenthal, J. A., Helms, M. J., Luecken, L., Pieper, C. P., Siegler, I. C., \& Suarez, E. C. (1997). Psychosocial Correlates of Job Strain in a Sample of Working Women. Archives of General Psychiatry, 54, 543-548. https://doi.org/10.1001/archpsyc.1997.01830180061007

Wortman, C., Biernat, M., \& Lang, E. (1991). Coping with Role Overload. In M. Frankenhaeuser, U. Lundberg, \& M. A. Chesney (Eds.), Women, Work and Health. Stress and Opportunities (pp. 85-110). New York: Plenum Press. https://doi.org/10.1007/978-1-4615-3712-0_5

Yalom, I. D. (1995). Introduction. In C. Rogers (Ed.), A Way of Being (pp. 8-16). Boston, MA: Houghton Mifflin Co. 